\title{
Erythropoiesis-stimulating agents in oncology: a study-level meta-analysis of survival and other safety outcomes
}

\section{J Glaspy, , J Crawford ${ }^{2}$, J Vansteenkiste ${ }^{3}$, D Henry ${ }^{4}$, S Rao ${ }^{5}$, P Bowers ${ }^{5}$, JA Berlin ${ }^{5}$, D Tomita ${ }^{6}$, K Bridges ${ }^{6}$ and H Ludwig ${ }^{7}$}

'Department of Medicine-Hematology and Oncology, David Geffen School of Medicine at University of California, Los Angeles, 100 UCLA Medical Plaza, Suite 550, Los Angeles, CA 90095-6996 USA; ²Department of Medical Oncology, Duke University Medical Center, Box 3198,25178 Morris Building, Durham, NC 277 I 0 USA; ${ }^{3}$ Respiratory Oncology Unit (Pulmonology), University Hospital Gasthuisberg, Herestraat 49, Leuven B-3000, Belgium;

${ }^{4}$ Department of Medicine, Pennsylvania Hospital, 230 W Washington Square, Philadelphia, PA 19106 USA; ${ }^{5}$ Johnson \& Johnson Pharmaceutical Research and Development LLC, I 125 Trenton-Harbourton Road, PO Box 200, M/S K304, Titusville, New Jersey 08560 USA; ${ }^{6}$ Amgen Inc., Thousand Oaks, CA 91320 USA; ${ }^{7}$ First Department of Medicine, Center for Oncology and Haematology, Wilhelminenspital, Montleartstrasse 37, Vienna A-I I7I, Austria

BACKGROUND: Cancer patients often develop the potentially debilitating condition of anaemia. Numerous controlled studies indicate that erythropoiesis-stimulating agents (ESAs) can raise haemoglobin levels and reduce transfusion requirements in anaemic cancer patients receiving chemotherapy. To evaluate recent safety concerns regarding ESAs, we carried out a meta-analysis of controlled ESA oncology trials to examine whether ESA use affects survival, disease progression and risk of venous-thromboembolic events. METHODS: This meta-analysis included studies from the 2006 Cochrane meta-analysis, studies published/updated since the 2006 Cochrane report, and unpublished trial data from Amgen and Centocor Ortho Biotech. The 60 studies analysed (I5 323 patients) were conducted in the settings of chemotherapy/radiochemotherapy, radiotherapy only treatment or anaemia of cancer. Data were summarised using odds ratios (ORs) with 95\% confidence intervals (Cls).

RESULTS: Results indicated that ESA use did not significantly affect mortality (60 studies: $O R=1.06$; $95 \%$ Cl: 0.97-1.15) or disease progression (26 studies: $\mathrm{OR}=1.01$; $95 \% \mathrm{Cl}$ : 0.90-1.14), but increased the risk for venous-thromoboembolic events (44 studies: $\mathrm{OR}=1.48 ; 95 \% \mathrm{Cl}: 1.28-1.72)$.

CONCLUSION: Though this meta-analysis showed no significant effect of ESAs on survival or disease progression, prospectively designed, future randomised clinical trials will further examine the safety and efficacy of ESAs when used according to the revised labelling information.

British Journal of Cancer (2010) I 02, 30I-315. doi:10.1038/sj.bjc.6605498 www.bjcancer.com

Published online 5 January 2010

(c) 2010 Cancer Research UK

Keywords: erythropoiesis-stimulating agent; anaemia; oncology; meta-analysis

Cancer patients commonly develop anaemia due to either cancer itself or to treatments such as myelosuppressive chemotherapy (Groopman and Itri, 1999; Knight et al, 2004; Ludwig et al, 2004). During a large European survey of cancer patients with different tumour types and treatments, $67 \%$ of 13628 patients were anaemic (defined as haemoglobin level $<12 \mathrm{~g} \mathrm{dl}^{-1}$ $\left.\left(7.5 \mathrm{mmoll}^{-1}\right)\right)$ at some time during the survey; anaemia was reported in $75 \%$ of those patients who received chemotherapy (Ludwig et al, 2004). Anaemia has been reported to be a potential risk factor for increased mortality, decreased efficacy of cancer treatments and longer hospitalisations (Schwartz, 2007; Spence, 2007). Anaemia can also increase fatigue, leading to reduced physical functioning and reduced quality of life (Curt et al, 2000). Although red blood cell (RBC) transfusions quickly correct anaemia, the effect is transient and transfusions carry inherent

*Correspondence: Dr J Glaspy; E-mail: jglaspy@mednet.ucla.edu Received 2 April 2009; revised 17 November 2009; accepted 25 November 2009; published online 5 January 2010 risks, including exposure to infectious agents (Barbara, 2004) and transfusion-related acute lung injury (Looney et al, 2004). A recent meta-analysis by the Cochrane Collaboration of randomised trials, prospective cohorts and retrospective surveys has also revealed that colorectal cancer patients receiving transfusions perioperatively have an increased risk for cancer recurrence (Amato and Pescatori, 2006).

Erythropoiesis-stimulating agents (ESAs) include recombinant erythropoietic glycoproteins developed as an anaemia-therapy alternative to RBC transfusions and their associated risks. ESAs approved in the United States of America (US) for treating chemotherapy-induced anaemia (CIA) in patients with non-myeloid malignancies include Epoetin alfa (Ortho, 2009) and darbepoetin alfa (Amgen, 2009). ESAs are also approved for this indication in the European Union (EU) (EMEA, 2008; eMC, 2008). Many clinical trials have demonstrated the efficacy and short-term safety of ESAs for raising and maintaining haemoglobin concentrations and for reducing RBC-transfusion rates (Glaspy et al, 1997; Demetri et al, 1998; Gabrilove et al, 2001; Littlewood et al, 2001; Vansteenkiste 
et al, 2002; Hedenus et al, 2003). Without using ESAs about $40-50 \%$ of CIA patients require transfusions (Littlewood et al, 2001; Vansteenkiste et al, 2002; Hedenus et al, 2003). That ESA therapy can reduce fatigue symptoms and measurably improve quality of life has been reported in several ESA trials (Vansteenkiste et al, 2002; Cella et al, 2003), meta-analyses of ESA studies (Ross et al, 2006; Minton et al, 2008) and in evidence-based ESA guidelines (Bokemeyer et al, 2007).

Though two trials suggested that ESA use might increase survival (enhanced treatment effects due to increased tumour-cell oxygenation was one postulated mechanism) (Littlewood et al, 2001; Vansteenkiste et al, 2002), several subsequent trials reported that targeting a haemoglobin level of $\geqslant 12 \mathrm{~g} \mathrm{dl}^{-1}$ in cancer patients receiving chemotherapy resulted in greater mortality in the ESA arm (Hedenus et al, 2003; Leyland-Jones et al, 2005; Amgen, 2007; ODAC, 2008). An ESA-associated increase in mortality and/or disease progression has also been reported in some controlled studies conducted in cancer settings off-label for ESA use, such as patients receiving radiotherapy only (Henke et al, 2003; Overgaard et al, 2007) or patients with anaemia not receiving radiotherapy or chemotherapy (i.e., anaemia of cancer (AoC)) (Wright et al, 2007; Smith et al, 2008). These safety signals have been the subject of three meetings (in 2004, 2007 and 2008) between the Oncologic Drugs Advisory Committee (ODAC) to the Food and Drug Administration (FDA) and the two US companies that distribute ESAs (Amgen and Centocor Ortho Biotech, Horsham, PA, USA, which is a subsidiary of Johnson \& Johnson) (ODAC, 2008). Information on these safety signals has been added to the US and EU ESA-labelling information (EMEA, 2008; eMC, 2008; Amgen, 2009; Ortho, 2009). However, as an ESA-associated increase in mortality and disease progression has not been seen in a large number of other controlled ESA studies (Vansteenkiste et al, 2002; Blohmer et al, 2004; Machtay et al, 2007; Moebus et al, 2007; Pirker et al, 2008; Aapro et al, 2008a), those studies reporting adverse safety signals must be considered within the total body of evidence.

Meta-analysis is a well-established method to systematically evaluate available evidence, estimate an overall-treatment effect and explore sources of heterogeneity in reported findings (Egger et al, 1997). Four large meta-analyses of ESA trials in both approved and off-label oncology settings have recently been conducted (Bohlius et al, 2006; Ross et al, 2006; Seidenfeld et al, 2006; Bennett et al, 2008b). In the 2006 Cochrane Collaborative analysis (encompassing studies published or publicly available from 1985 to April 2005 that were conducted in the settings of chemotherapy only, radiotherapy with or without chemotherapy and AoC), 42 placebo- or standard-of-care-controlled ESA oncology trials were meta-analysed for survival (8167 patients) (Bohlius et al, 2005, 2006). The pooled results indicated a statistically non-significant numerical increase in mortality risk associated with ESA use (the odds ratio (OR) was 1.08 with a $95 \%$ confidence interval (CI) of 0.99-1.18 for ESA-treated patients $v s$ control patients). Similar findings were reported in a meta-analysis by Ross et al (2006) and in the Seidenfeld et al (2006) metaanalysis from the US Agency for Healthcare Research and Quality (AHRQ) (Ross et al, 2006; Seidenfeld et al, 2006). Several smaller meta-analyses have also reported that ESA use has a nonsignificant effect on survival in cancer patients (Hedenus et al, 2005; Aapro et al, 2006, 2008b; Boogaerts et al, 2006). However, a recent large meta-analysis by Bennett et al (2008b) of 13611 patients in 51 phase 3, controlled ESA oncology trials conducted in the chemotherapy, radiotherapy only and AoC settings indicated that mortality was significantly higher in the ESA group (Hazard ratio $(\mathrm{HR})=1.10 ; 95 \% \mathrm{CI}: 1.01-1.20 ; P=0.03$ ) (Bennett et al, 2008b).

To comprehensively examine whether ESA use affects safety outcomes in cancer patients, we conducted a meta-analysis that included (1) studies included in the Cochrane 2006 meta-analysis,
(2) controlled ESA studies in oncology published after April 2005 (the cut-off date for the Bohlius et al 2006 Cochrane review) up to March 2008 and (3) the most recent, updated ESA-trial data provided by Amgen and Centocor Ortho Biotech for unpublished and published trials (these data were not available for the recent Bennett et al (2008b) meta-analysis mentioned above). A total of 60 studies with survival data were identified, including all 51 studies analysed in Bennett et al (2008b). As the efficacy of ESAs for increasing haemoglobin levels and reducing transfusion requirements is well-established (Bohlius et al, 2006), our metaanalyses focused on the effect of ESA use on survival, disease progression and risk of venous-thromboembolic events (VTEs).

\section{PATIENTS AND METHODS}

\section{Search strategy}

The 2006 Cochrane Collaborative report (specifically Analysis 05.05) (Bohlius et al, 2006) was used as the basis for the present, updated meta-analysis. To identify studies published since the 2006 Cochrane report (i.e., from April 2005 to March 2008), we carried out a literature search of the BIOSIS Previews, Current Contents, EMBASE and Ovid MEDLINE databases using the following Boolean search string - 'erythropoiesis stimulating proteins (including all synonymous terms)' and 'cancer (including 'neoplasm' and 'malignancy')'. A search was also carried out for relevant abstracts and associated poster presentations delivered from 1995 to 2007 at conferences for the American Society of Clinical Oncology (ASCO), American Society of Hematology (ASH), San Antonio Breast Cancer Symposium (SABCS) and the European Society for Medical Oncology (ESMO). Studies were selected if they were randomised, controlled trials of cancer patients treated with an ESA (Epoetin alfa, epoetin beta or darbepoetin alfa) plus transfusions compared with control patients who either received placebo or best standard of care for prophylaxis or treatment of anaemia (e.g., transfusions without ESAs). Studies had to report on death or percentage of death in each treatment group or to have collected mortality data that were available for analysis. Interim analyses of ESA trials were included, as well as ESA studies that examined iron use in cancer patients. One study (Blohmer et al, 2004) was rejected from the 2006 Cochrane analysis because oral iron was used in the ESA group and not the control group. This study was included in our analysis as it reported survival data, no evidence exists to suggest that oral iron supplementation affects mortality, and many ESA studies recommend iron supplementation to maintain adequate iron availability for erythropoiesis (Auerbach et al, 2004; Bastit et al, 2008).

We excluded those publications that were not written in English, that were editorials, letters, clinical guidelines or case studies, and that allowed ESAs to be administered to the control arm as part of standard medical care. If two publications existed describing the same study (e.g., an abstract and a manuscript), the most recent publication was used. For studies conducted by Amgen and Centocor Ortho Biotech, current data available from internal databases for those randomised, controlled ESA trials that met the search criteria used in the literature search were included in the analyses. Database results did not always match previously published results because longer-term follow-up data became available or because interim data were updated with either more recent interim data or the final data. In addition, death, disease progression and incidence of VTEs were frequently described as safety endpoints in the published literature and therefore, published studies usually analysed patients by treatment received. In this study-level meta-analysis, analyses used an intention-totreat or modified-intention-to-treat approach (patients who received study drug were analysed). If data were not available by randomised-treatment assignment, only then were the published results used. Data for epoetin beta studies were collected from 
publications only and were not supplemented from internal databases at Hoffmann-La Roche (Basel, Switzerland).

Three modifications were made to the 2006 Cochrane analytical approach (Bohlius et al, 2006). First, our analysis collapsed chemotherapy groups used in the 2006 Cochrane meta-analysis to a single group, as ESA-labelling information does not differentiate between chemotherapy regimens with and without platinum and because the 2006 Cochrane mortality results were not significantly different between chemotherapy groups. Second, trials in which a majority of patients received chemotherapy (with or without radiotherapy) were classified as chemotherapy studies; in the 2006 Cochrane analysis, studies in which patients received radiotherapy and chemotherapy were classified as radiotherapy studies. Of note, one study labelled as a radiotherapy study in the 2006 Cochrane analysis (Wright et al, 2007) excluded patients who were to receive curative radiation. This study was classified as an AoC study in the present meta-analysis. Third, unlike the Cochrane analysis, we excluded studies in patients with myelodysplastic syndromes (MDS), as ESAs are not approved for use in MDS, which is a separate disease from cancer. One study included in the Cochrane 2006 report as an AoC study (Thompson et al, 2000) was excluded from the present meta-analysis because it was an MDS study.

Studies identified from the above literature search that also reported data on the relationship between ESA use and disease progression or VTE risk were meta-analysed to examine these relationships. Additional literature searches did not identify any additional controlled, ESA oncology studies reporting data on ESA use and disease progression or VTE risk.

\section{Statistical analyses}

Data were summarised using ORs generated using the Comprehensive Meta-Analysis (V2) software. In contrast, the 2006 Cochrane Collaboration approach (Bohlius et al, 2006) reported either an OR or HR. As the method by which an OR is calculated provides a point estimate farther from unity (i.e., an estimate further from the null) than that provided by an HR, an OR is a more conservative estimate and may be more likely to detect a safety signal. Data are presented as a forest plot of all studies with an estimated OR and 95\% CI. A random-effects model was used because it assumes treatment effects are not identical in all studies. Some analyses also used a fixed-effects model, which assumes that the treatment effect is the same in each study and that differences in results are due only to chance. Heterogeneity among studies was quantified using the $I^{2}$ inconsistency statistic, which is a measure of inter-study variability as a proportion of total variability. When inter-study variability is low, the fixed-effects and random-effects models will yield very similar results.

For the present meta-analyses, both 1-year and long-term follow-up survival data were available from the Breast Cancer Erythropoietin Survival Trial (BEST study) (Leyland-Jones et al, 2005; Centocor Ortho Biotech, data on file). The 1-year BEST data were used in the figures. For completeness, results using the BEST long-term follow-up data are also provided within the text. The long-term data from BEST were collected after the end of the 1 -year randomised period. For chemotherapy studies, an influence plot was generated that shows the estimated OR for mortality if an individual chemotherapy study (such as BEST) was excluded from the analysis.

As we did not have patient-level data for many of the studies included in this study-level meta-analysis, an overall-mortality HR was not calculated. However, sensitivity analyses were carried out on 20 chemotherapy studies with long-term follow-up $(>6$ months) to address concerns regarding the use of $\mathrm{OR}$ as a point estimate in a meta-analysis. Patient-level data from 16 of the 20 studies were obtained from Amgen and Centocor Ortho Biotech. In all, 4 of the 20 chemotherapy studies could not be included in the patient-level analysis as primary data were not available (Osterborg et al, 2005; Engert, 2007; Strauss et al, 2008; Aapro et al, 2008a). However, the published manuscripts for Aapro et al (2008a) and Osterborg et al (2005) provided HRs for survival. Thus, sensitivity analyses were also carried using the published HRs for these two studies. Data were combined and HRs for mortality were calculated for each study and across all studies combined (with study as a stratification factor) using an unadjusted Cox's proportional hazards model.

\section{RESULTS}

\section{Study selection}

The literature search for controlled, ESA oncology trials that reported mortality or survival data identified 60 studies. In all, 19 were additional ESA studies that were added to 41 studies identified from the 2006 Cochrane meta-analysis of survival in ESA oncology trials (Bohlius et al, 2006) (Table 1). Of note, of the

Table I

Characteristics of the 60 studies examined in the present meta-analysis

\begin{tabular}{|c|c|c|c|c|}
\hline Study publication & Study number or alias & Treatment setting & Tumour type & $\begin{array}{l}\text { Number } \\
\text { patients an }\end{array}$ \\
\hline \multicolumn{5}{|c|}{ Studies not present in Cochrane 2006} \\
\hline${ }^{a}$ Aapro et al, 2008a & BRAVE & Chemotherapy & Breast & 463 \\
\hline a,bBlohmer et al, 2004 & $\begin{array}{l}\text { AGO/NOGG } \\
\text { EPO-GER-8 }\end{array}$ & Chemotherapy & Cervical & 250 \\
\hline Charu et al, 2007 & AMG 20000219 & AoC & Non-myeloid & 285 \\
\hline a,b Debus et al, 2006 & EPO-GER-22 & Chemotherapy & NSCLC & 385 \\
\hline Engert, 2007 & HD- 15 & Chemotherapy & Hodgkin's lymphoma & 688 \\
\hline Gordon et al, 2006 & AMG 20030204 & AoC & Non-myeloid & 218 \\
\hline aMilroy et al, 2003 & EPO-INT-49 & Chemotherapy & NSCLC & 424 \\
\hline Moebus et al, 2007 & EPO-GER-7 & Chemotherapy & Breast & 643 \\
\hline Mystakidou et al, 2005 & N/A & AoC & Solid tumour & 100 \\
\hline Overgaard et al, 2007 & $\begin{array}{l}\text { SE-2002-900I } \\
\text { (DAHANCA-10) }\end{array}$ & Radiotherapy & Head and neck & 515 \\
\hline 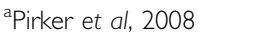 & AMG 20010145 & Chemotherapy & SCLC & 596 \\
\hline Pronzato et al, 2002 & EPO-INT-47 & Chemotherapy & Breast & 223 \\
\hline${ }^{\mathrm{a} S}$ mith et al, 2008 & AMG 20010103 & AoC & Non-myeloid & 985 \\
\hline bstrauss et al, 2008 & MARCH & Chemotherapy & Cervical & 74 \\
\hline Taylor et al, 2005 & AMG 20030232 & Chemotherapy & Non-myeloid & 386 \\
\hline Wilkinson et al, 2006 & EPO-INT-45 & Chemotherapy & Ovarian & 181 \\
\hline aUnpublished & PREPARE & Chemotherapy & Breast & 733 \\
\hline
\end{tabular}


Table I (Continued)

\begin{tabular}{|c|c|c|c|c|}
\hline Study publication & Study number or alias & Treatment setting & Tumour type & $\begin{array}{c}\text { Number of } \\
\text { patients analysed }\end{array}$ \\
\hline Unpublished & EPO-CAN-203 & AoC & $N / A$ & $17^{c}$ \\
\hline Unpublished & EPO-CAN-303 & AoC & N/A & $16^{c}$ \\
\hline \multicolumn{5}{|c|}{ Studies included in Cochrane 2006 that had updates since Cochrane 2006} \\
\hline Chang et al, 2005 & EPO-CAN- 17 & Chemotherapy & Breast & 354 \\
\hline${ }^{\mathrm{b}}$ Goss et al, 2005 & EPO-CAN-I 5 & Chemotherapy & SCLC & 104 \\
\hline${ }^{a}$ Grote et al, 2005 & N93-004 & Chemotherapy & SCLC & 224 \\
\hline aHedenus et al, 2003 & AMG 20000161 & Chemotherapy & Haematological & 344 \\
\hline aLeyland-Jones et al, 2005 & $\begin{array}{l}\text { EPO-INT-76 } \\
\text { (BEST) }\end{array}$ & Chemotherapy & Breast & 939 \\
\hline aMachtay et al, 2007 & $\begin{array}{l}\text { RTOG-99-03 } \\
\text { PR99-03-046 }\end{array}$ & Radiotherapy & Head and neck & 148 \\
\hline Razzouk et al, 2006 & CR002296 & Chemotherapy & Solid or various haematological & 224 \\
\hline Savonije et al, 2005 & EPO-NED- 17 & Chemotherapy & Solid tumours & 315 \\
\hline a,bThomas et al, 2008 & GOG-0191 & Chemotherapy & Cervical & 114 \\
\hline aVansteenkiste et al, 2002 & AMG 980297 & Chemotherapy & SCLC and NSCLC & 314 \\
\hline aWright et al, 2007 & EPO-CAN-20 & AoC & NSCLC & 70 \\
\hline Unpublished & EPO-INT-I & Chemotherapy & Ovarian & 246 \\
\hline Unpublished & EPO-INT-3 & Chemotherapy & Solid or various haematological & 201 \\
\hline anpublished & EPO-GBR-7 & Radiotherapy & Head and neck & 300 \\
\hline \multicolumn{5}{|c|}{ Studies included in Cochrane 2006 that have had no updates } \\
\hline Abels, 1993 & N/A & AoC & Mixed & 124 \\
\hline Bamias et al, 2003 & N/A & Chemotherapy & Solid tumour & 144 \\
\hline Cascinu et al, 1994 & N/A & Chemotherapy & Mixed & 100 \\
\hline Case et al, 1993 & N/A & Chemotherapy & Mixed & 157 \\
\hline Cazzola et al, 1995 & MF4313 & Chemotherapy & $\begin{array}{l}\text { Multiple myeloma or } \\
\text { non-Hodgkin's lymphoma }\end{array}$ & 146 \\
\hline Coiffier et al, 200। & MF442I & Chemotherapy & Mixed & 262 \\
\hline Dammacco et al, 200। & EPO-INT-2 & Chemotherapy & Multiple myeloma & 145 \\
\hline Del Mastro et al, 1997 & N/A & Chemotherapy & Breast & 62 \\
\hline Dunphy et al, 1999 & N/A & Chemotherapy & Head and neck or lung carcinoma & 30 \\
\hline Hedenus et al, 2002 & AMG 9901।4 & Chemotherapy & Lymphoproliferative & 66 \\
\hline Henke et al, 2003 & ENHANCE & Radiotherapy & Head and neck & 351 \\
\hline Henry et al, 1995 & N/A & Chemotherapy & Mixed & 132 \\
\hline Kotasek et al, 2003 & AMG 98029। & Chemotherapy & Solid tumours & 249 \\
\hline Kurz et al, 1997 & N/A & Chemotherapy & Gynaecological & 35 \\
\hline aLittlewood et al, 200। & EPO-INT-IO & Chemotherapy & Solid or non-myeloid malignancy & 375 \\
\hline Oberhoff et al, 1998 & N/A & Chemotherapy & Solid tumours & 218 \\
\hline O'Shaughnessy et al, 2005 & PR00-27-005 & Chemotherapy & Breast & 100 \\
\hline Osterborg et al, 1996 & MF4250 & Chemotherapy & Haematological & 144 \\
\hline${ }^{a}$ Osterborg et al, 2005 & MF4467 & Chemotherapy & Haematological & 343 \\
\hline Pangalis et al, 1995 & P-174 & Chemotherapy & B-chronic lymphocytic leukaemia & 45 \\
\hline Rose et al, 1994 & 189-040 & Chemotherapy & Chronic lymphocytic leukaemia & 221 \\
\hline Smith et al, 2003 & AMG 9901।1 & AoC & Mixed & 86 (Q3W/Q4W) \\
\hline ten Bokkel Huinink et al, 1998 & N/A & Chemotherapy & Ovarian & 120 \\
\hline Thatcher et al, 1999 & CC2574-P-169 & Chemotherapy & SCLC & 130 \\
\hline 'Throuvalas et al, 2000 & N/A & Chemotherapy & Cervix or bladder & 55 \\
\hline badhan-Raj et al, 2004 & PR00-03-006 & Chemotherapy & Gastric and rectal & 60 \\
\hline Witzig et al, 2005 & PR98-27-008 & Chemotherapy & Mixed & 344 \\
\hline
\end{tabular}

Abbreviations: $\mathrm{AoC}=$ anaemia of cancer; $\mathrm{N} / \mathrm{A}=$ not available; NSCLC = non-small-cell lung cancer; SCLC=small-cell lung cancer; $\mathrm{Q} 3 \mathrm{~W}=$ every 3 weeks; $\mathrm{Q} 4 \mathrm{~W}=$ every 4 weeks. ${ }^{a}$ These studies have reported a mortality hazard ratio that is publicly available in a journal or abstract publication, the ODAC (2008) briefing book or in Hedenus et al (2005). ' Patients received chemotherapy and radiotherapy. 'The planned enrolment was 160 patients for EPO-CAN-203 and 540 patients for EPO-CAN 303. Both studies were stopped early because of poor accrual (Centocor Ortho Biotech, data on file).

42 studies included in the 2006 Cochrane survival analysis, 1 study was excluded from the present analysis as it was conducted in MDS patients (Thompson et al, 2000). Of the 19 additional studies, 12 were in the chemotherapy setting, 1 was in the radiotherapy alone setting and 6 were in AoC; for some of the 19 studies, updated, unpublished data from Amgen and Centocor Ortho Biotech were included in the present meta-analysis. Of the 41 studies selected from the Cochrane 2006 report, 14 were identified as having updated data available (e.g., results previously published in abstracts were now available as final publications or updated data were available from Amgen or Centocor Ortho Biotech) (Table 1). In this literature review, the 60 identified studies were conducted in patients with solid tumours and/or haematological malignancies who received an ESA (Epoetin alfa, epoetin beta or darbepoetin alfa) or control treatment (placebo or best standard of care). Only one study was conducted in paediatric patients (Razzouk et al, 2006). Of the 60 studies, 26 reported disease progression outcomes and 44 reported on the incidence of VTEs.

\section{Mortality}

Mortality was assessed in 60 randomised, controlled trials (41 from the 2006 Cochrane analysis plus 19 additional studies) involving 15323 patients (Figure 1). A total of 9 studies were in the AoC 

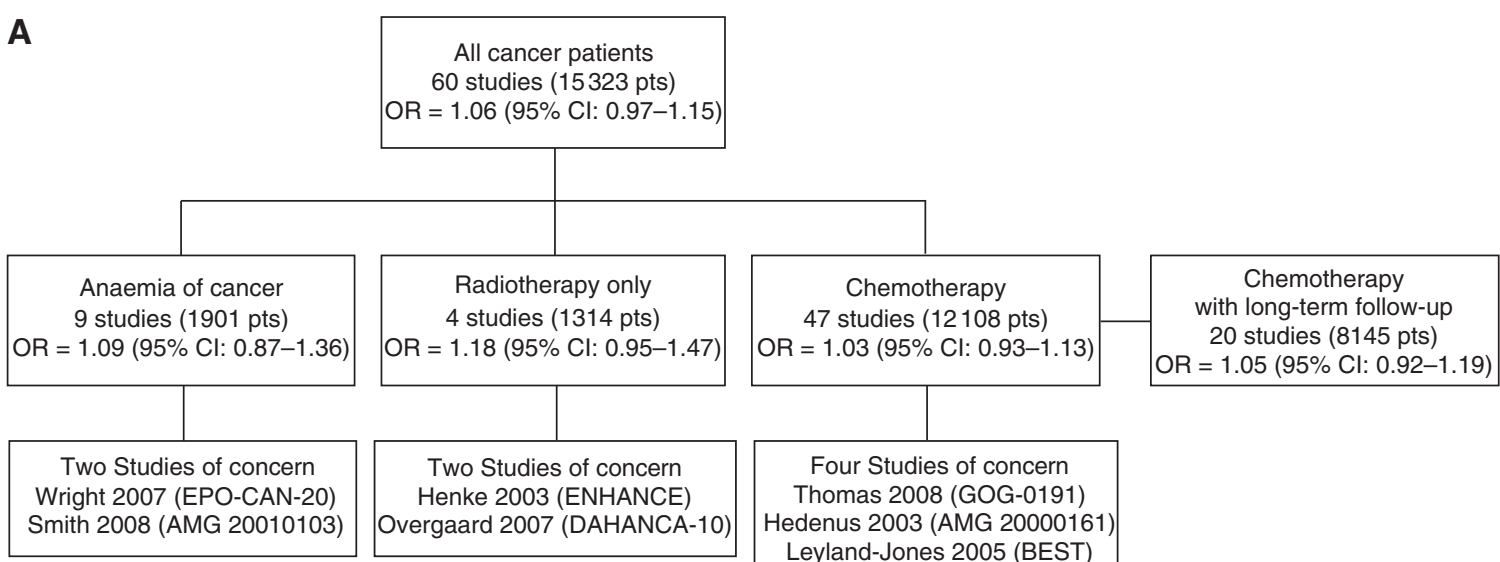

Four Studies of concern Thomas 2008 (GOG-0191) Hedenus 2003 (AMG 20000161)

Leyland-Jones 2005 (BEST) Amgen 2007 (PREPARE)

B

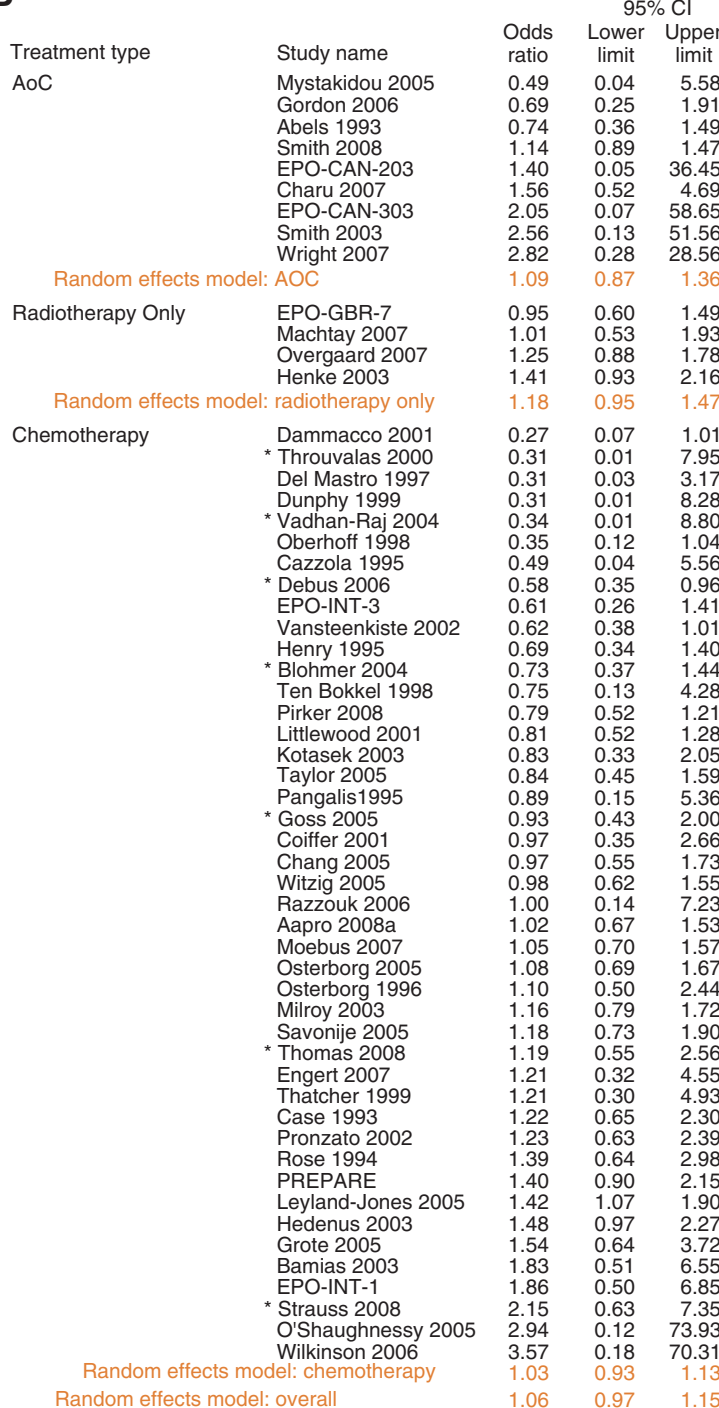

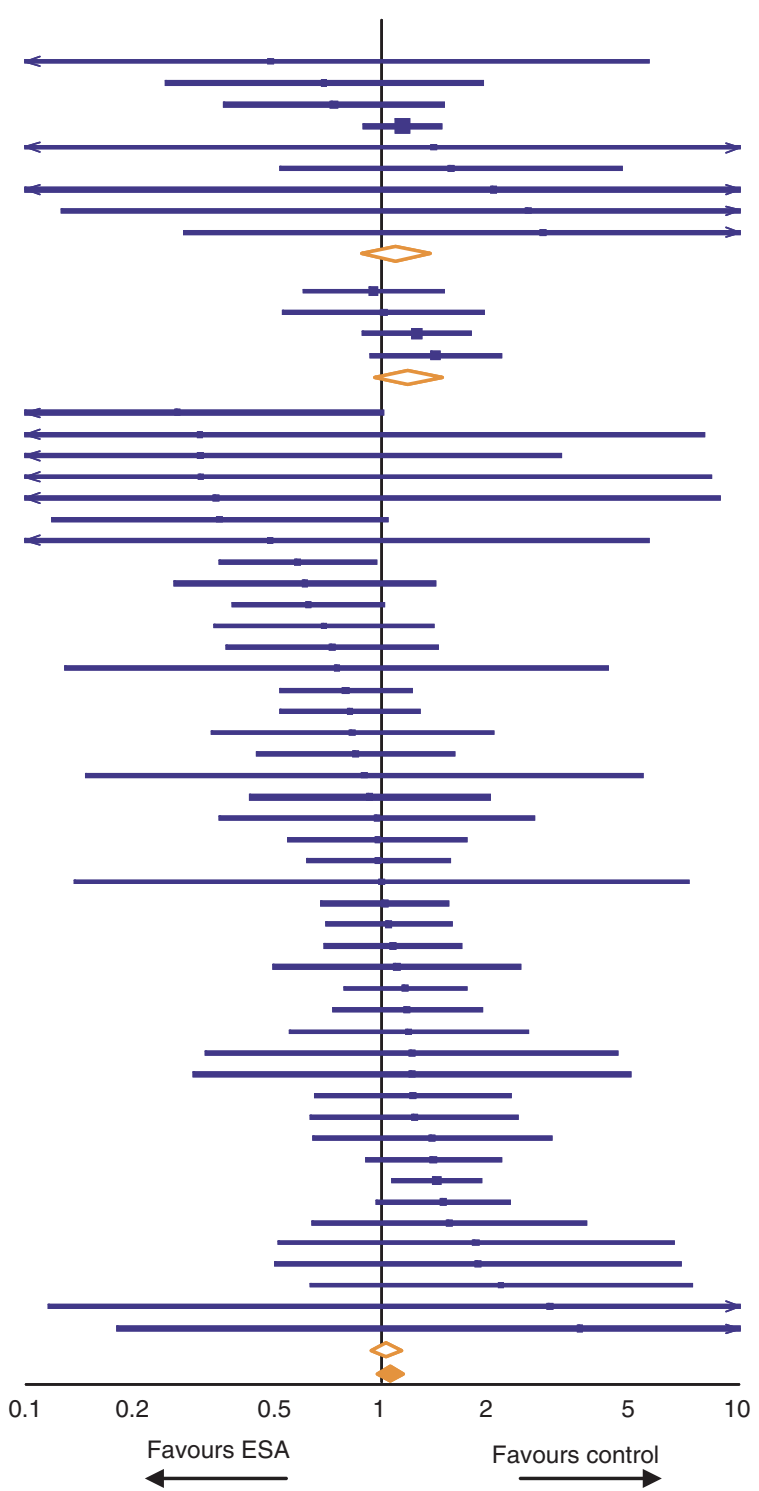

Figure I Continued. 


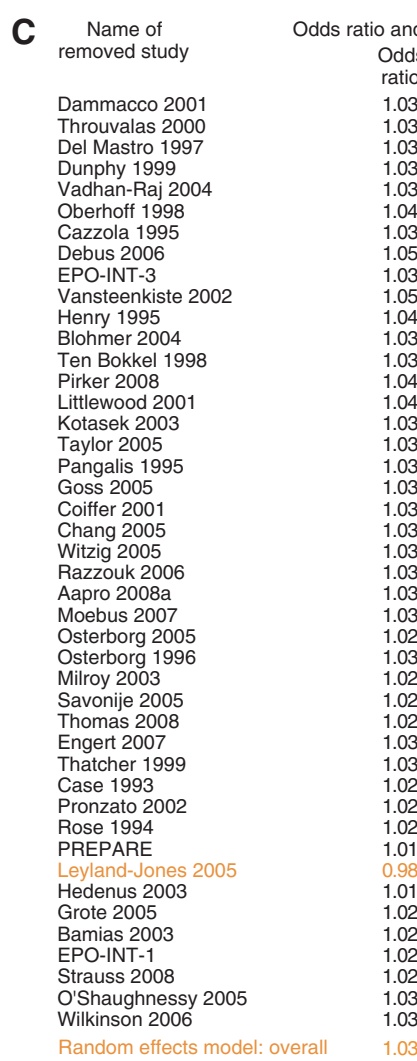

$\% \mathrm{Cl}$ with each study removed

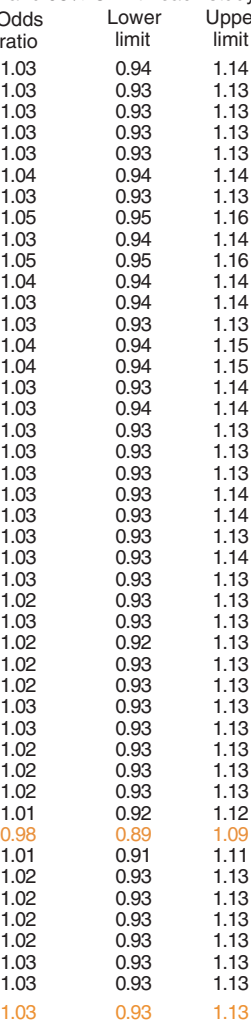

Upper

Dammacco 2001 Dunphy 1999 azzola 199 (a)

ansteenkiste 2002 Henry 1995

Ten Bokkel 1998

ittlewood 2001

Kotasek 2003

Pangalis 199

Goss 2005

Coiffer 2001

Witzig 2005

Aapro 2008a

Moebus 2007

Osterborg 1996

Milroy 2003

Sav 2008

Thatcher 1999

Hedenus 2003

Wilkinson 2006

Random effects model: overal

$0.93 \quad 1.13$

D

Study name

* Debus 2006

Vansteenkiste 2002

* Blohmer 2004

Pirker 2008

Littlewood 2001

Chang 2005

Witzig 2005

Aapro 2008a

Moebus 2007

Osterborg 2005

Milroy 2003

Savonije 2005

* Thomas 2008

Engert 2007

Pronzato 2002

PREPARE

Leyland-Jones 2005

Hedenus 2003

Grote 2005

* Strauss 2008

Random effects model

\begin{tabular}{|c|c|c|}
\hline $\begin{array}{l}\text { Odds } \\
\text { ratio }\end{array}$ & $\begin{array}{l}95 \% \\
\text { Lower } \\
\text { limit }\end{array}$ & $\begin{array}{l}\text { Upper } \\
\text { limit }\end{array}$ \\
\hline 0.58 & 0.35 & 0.96 \\
\hline 0.62 & 0.38 & 1.01 \\
\hline 0.73 & 0.37 & 1.44 \\
\hline 0.79 & 0.52 & 1.21 \\
\hline 0.81 & 0.52 & 1.28 \\
\hline 0.97 & 0.55 & 1.73 \\
\hline 0.98 & 0.62 & 1.55 \\
\hline 1.02 & 0.67 & 1.53 \\
\hline 1.05 & 0.70 & 1.57 \\
\hline 1.08 & 0.69 & 1.67 \\
\hline 1.16 & 0.79 & 1.72 \\
\hline 1.18 & 0.73 & 1.90 \\
\hline 1.19 & 0.55 & 2.56 \\
\hline 1.21 & 0.32 & 4.55 \\
\hline 1.23 & 0.63 & 2.39 \\
\hline 1.40 & 0.90 & 2.15 \\
\hline 1.42 & 1.07 & 1.90 \\
\hline 1.48 & 0.97 & 2.27 \\
\hline 1.54 & 0.64 & 3.72 \\
\hline 2.15 & 0.63 & 7.35 \\
\hline 1.05 & 0.92 & 1.19 \\
\hline
\end{tabular}

$0 . \overline{5}$

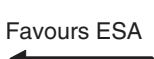

1

Favours control

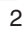

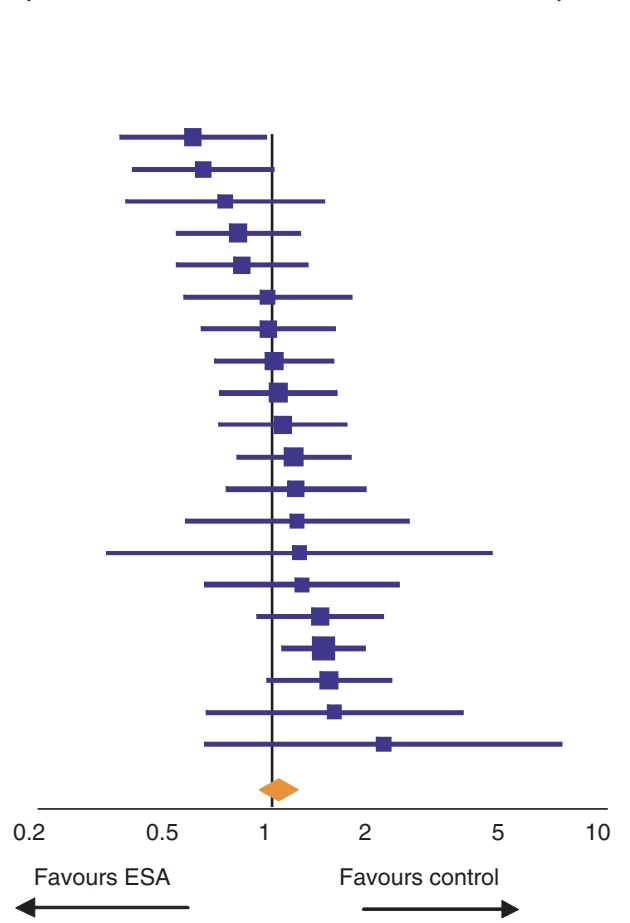

Figure I Effect of erythropoiesis-stimulating agent (ESA) use on mortality. (A) Flow diagram of studies analysed. The odds ratio (OR) (95\% confidence interval (Cl)) for the mortality of all 60 studies and for each cancer setting is given. Pts indicates patients. (B) Meta-analysis of mortality using 60 controlled studies carried out in the settings of chemotherapy, anaemia of cancer (AoC) or radiotherapy only. This analysis included 15323 patients, with 8343 ESA-treated patients and 6980 control patients. An asterisk denotes radiochemotherapy studies. Three chemotherapy studies are not listed, as they reported no deaths in the ESA or control arms. (C) Influence of each chemotherapy study on the mortality OR for all chemotherapy studies. This analysis calculated the mortality OR for the chemotherapy studies combined after excluding each listed chemotherapy study. Of the 47 chemotherapy studies identified, 3 were not listed in the plot as they reported no deaths in the ESA or control arms. (D) Study-level meta-analyses of mortality in 20 chemotherapy studies with long-term follow-up. This analysis included 8145 patients, with 4I83 ESA-treated patients and 3962 control patients. An asterisk denotes radiochemotherapy studies. 
setting, 4 in the radiotherapy only setting and 47 in the chemotherapy setting. Of note, 3 of the 47 chemotherapy studies reported no deaths in either treatment arm (Cascinu et al, 1994; Kurz et al, 1997; Hedenus et al, 2002) and, thus, only 44 chemotherapy studies are listed in the plot shown in Figure 1B. Long-term follow-up ( $>6$ months after the randomised study period) was reported in 26 studies (20 were chemotherapy studies), whereas the remaining 34 studies evaluated deaths on study.

Meta-analysis of all 60 studies based on a random-effects model yielded an OR for mortality of 1.06 (95\% CI: $0.97-1.15$; results were the same when a fixed-effects model was used) (Figure $1 \mathrm{~A}$ and $\mathrm{B}$; Table 2). There was little heterogeneity among the trials $\left(I^{2}=0 \%\right)$. This analysis included the 1-year survival data from the BEST study, which indicated higher mortality with ESA use in breast cancer patients (Leyland-Jones et al, 2005). However, this mortality signal has not been observed in long-term follow-up BEST data (ODAC, 2008). If long-term follow-up BEST data (i.e., survival data collected beyond the 1-year treatment period) were included (Leyland-Jones et al, 2005; ODAC, 2008), the mortality OR was 1.02 (95\% CI: $0.94-1.11 ; I^{2}=0 \%$ ) using either the randomeffects or fixed-effects model.

Meta-analysis of the 47 chemotherapy studies (12 108 patients) with either the random- or fixed-effects model resulted in an OR for mortality of 1.03 (95\% CI: $0.93-1.13 ; \mathrm{I}^{2}=1.2 \%$ ) (Figure $1 \mathrm{~A}$ and B; Table 2). The BEST study provided the greatest weight $(11.4 \%)$ in this analysis. The influence plot (Figure 1C) shows the effect of removing the BEST study (with 1-year data) from the metaanalysis of the chemotherapy studies; only removal of the BEST study shifted the mortality OR to $<1$. Meta-analysis of the 47 chemotherapy studies with the long-term follow-up BEST data resulted in a mortality OR of 0.98 (95\% CI: $0.89-1.08)$ using either a random- or fixed-effects model. Meta-analyses of mortality in the off-label uses of AoC (9 studies; 1901 patients) and radiotherapy only (4 studies; 1314 patients) yielded an OR higher than that observed for the chemotherapy studies (Figure 1A and B; Table 2).

Studies in the chemotherapy setting that reported a meanbaseline haemoglobin concentration were analysed stratified by the baseline haemoglobin concentration at study entry. This analysis (Table 2) indicated a non-significant effect of ESAs on mortality in studies with a reported mean-baseline haemoglobin concentration of $<10 \mathrm{~g} \mathrm{dl}^{-1}$ or $10-12 \mathrm{~g} \mathrm{dl}^{-1}$.

When mortality in the 20 chemotherapy studies with long-term follow-up data (8145 patients) was analysed, the mortality OR was 1.05 (95\% CI: $0.92-1.19 ; I^{2}=25.1 \%$ ) using a random-effects model (Figure 1A and D) and 1.06 (95\% CI: 0.96-1.18) using a fixed-effects model. If BEST long-term follow-up data were included (LeylandJones et al, 2005; ODAC, 2008), the mortality OR was 1.00 (95\% CI: $\left.0.89-1.12 ; I^{2}=10.4 \%\right)$ using a random-effects model or $1.00(95 \%$ CI: $0.90-1.11$ ) using a fixed-effects model. Sensitivity analyses of the 20 chemotherapy trials with long-term follow-up survival data examined if OR estimates are effective for examining survival in meta-analyses. Study-level ORs and both study-level and patientlevel HRs were estimated for mortality. Primary patient-level data (obtained from Amgen and Centocor Ortho Biotech) and data from the published literature were used. Though there are small variations, the estimates summarizing the mortality results across studies appeared to be consistent in indicating a small and non-significant effect of ESA use on mortality in the chemotherapy setting (Table 3).

\section{Disease progression}

Of the 60 controlled ESA trials that measured survival, 26 included a measure of disease progression (21 chemotherapy studies, 1 AoC study and 4 radiotherapy only studies) (Figure $2 \mathrm{~A}$ ). The diseaseprogression outcomes used (e.g., progression-free survival, relapse-free survival, local-regional relapse, tumour response or disease progression) and the quality of the tumour assessments

Table 2 Risk of death in patients receiving ESAs compared with patients not receiving ESAs: results from five meta-analyses

\begin{tabular}{|c|c|c|c|c|}
\hline & Number of trials & Number of patients & Statistic & $95 \%$ Confidence interval \\
\hline Current meta-analysis, All studies & 60 & 15323 & $1.06 \bigcirc R$ & $0.97-1.15$ \\
\hline Chemotherapy studies & 47 & 12108 & $1.03 \mathrm{OR}$ & $0.93-1.13$ \\
\hline Mean entry haemoglobin $<10 \mathrm{~g} 100 \mathrm{ml}^{-1}$ & 16 & 3265 & $0.99 \mathrm{OR}$ & $0.80-1.22$ \\
\hline 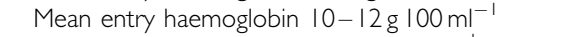 & 13 & 3661 & $0.91 \mathrm{OR}$ & $0.77-1.08$ \\
\hline Mean entry haemoglobin $>12 \mathrm{~g} \mathrm{l}^{0} \mathrm{ml}^{-1}$ & 13 & 4522 & $1.13 \mathrm{OR}$ & $0.94-1.36$ \\
\hline AoC studies & 9 & 1901 & $1.09 \mathrm{OR}$ & $0.87-1.36$ \\
\hline Radiotherapy studies & 4 & 1314 & $1.18 \mathrm{OR}$ & $0.95-1.47$ \\
\hline Cochrane (Bohlius et al, 2006), All studies & 42 & 8167 & $1.08 \mathrm{OR}$ & $0.99-1.18$ \\
\hline All studies, entry haemoglobin $<10 \mathrm{~g} 100 \mathrm{ml}^{-1}$ & 20 & 3765 & $1.01 \mathrm{OR}$ & $0.89-1.15$ \\
\hline All studies, entry haemoglobin $10-<12 \mathrm{~g} \mathrm{I}^{0} \mathrm{ml}^{-1}$ & 8 & 1712 & $0.98 \mathrm{OR}$ & $0.82-1.16$ \\
\hline 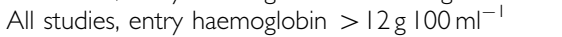 & 7 & 1696 & $1.27 \mathrm{OR}$ & $1.05-1.54$ \\
\hline Chemotherapy studies ${ }^{\mathrm{a}}$ & 30 & 6282 & $1.02 \mathrm{OR}$ & $0.90-1.15$ \\
\hline AoC studies & 3 & 276 & $1.14 \mathrm{OR}$ & $0.56-2.31$ \\
\hline Radiotherapy studies & 8 & 1187 & $1.27 \mathrm{OR}$ & $1.05-1.55$ \\
\hline AHRQ (Seidenfeld et al, 2006), All studies & 39 & 7891 & I.08 Peto OR & $0.98-1.18$ \\
\hline All studies, entry haemoglobin $<10 \mathrm{~g} 100 \mathrm{ml}^{-1}$ & 17 & 3489 & I.0I Peto OR & $0.89-1.15$ \\
\hline 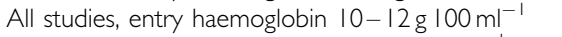 & 8 & 1712 & 0.98 Peto OR & $0.82-1.16$ \\
\hline All studies, entry haemoglobin $>12 \mathrm{~g}^{0} 00 \mathrm{ml}^{-1}$ & 7 & 1696 & I.27 Peto OR & $1.05-1.54$ \\
\hline (Ross et al, 2006), All studies & 17 & 2895 & $1.14 \mathrm{OR}$ & $0.90-1.45$ \\
\hline $\mathrm{ClA}$ studies (entry haemoglobin $<1|\mathrm{~g}| 00 \mathrm{ml}^{-1}$ ) & $1 \mid$ & 2014 & $0.99 \mathrm{OR}$ & $0.72-1.36$ \\
\hline Non-CIA studies & 6 & 881 & $1.39 \mathrm{OR}$ & $0.96-2.00$ \\
\hline (Bennett et al, 2008b), All studies & 51 & 13611 & $1.10 \mathrm{HR}$ & $1.01-1.20$ \\
\hline Chemotherapy or radiotherapy studies & 45 & | 1522 & I.09 HR & $0.99-1.19$ \\
\hline AoC studies & 6 & 1800 & $1.29 \mathrm{HR}$ & $1.00-1.67$ \\
\hline
\end{tabular}

Abbreviations: All studies = all studies analysed from settings of chemotherapy, anaemia of cancer and radiotherapy only; AoC $=$ anaemia of cancer; $\mathrm{CIA}=$ chemotherapyinduced anaemia; ESA = erythropoiesis-stimulating agent; $H R=$ hazard ratio; $\mathrm{OR}=$ odds ratio. ${ }^{a}$ Estimated by Amgen based on original classification of studies from the Cochrane 2006

meta-analysis (Bohlius et al, 2006). 
Table 3 Sensitivity analysis of odds ratio ${ }^{a}$ vs hazard ratio ${ }^{b}$ for estimating mortality in chemotherapy studies with long-term follow-up

\begin{tabular}{|c|c|c|c|c|}
\hline $\begin{array}{l}\text { Number of } \\
\text { studies analysed }\end{array}$ & Studies excluded & $\begin{array}{l}\text { Summary } \\
\text { measure }\end{array}$ & $\begin{array}{c}\text { Point } \\
\text { estimate }\end{array}$ & $95 \% \mathrm{Cl}$ \\
\hline 20 & None & $\begin{array}{l}\text { Study-level } \\
\text { OR }\end{array}$ & 1.05 & $0.92-1.19$ \\
\hline 18 & Engert, 2007; Strauss et al, 2008 & $\begin{array}{l}\text { Study-level } \\
\text { HR }\end{array}$ & 1.04 & $0.95-1.14$ \\
\hline 16 & Engert, 2007; Osterborg et al, 2005; Aapro et al, 2008a; Strauss et al, 2008 & $\begin{array}{l}\text { Study-level } \\
\text { OR }\end{array}$ & 1.04 & $0.89-1.21$ \\
\hline 16 & Engert, 2007; Osterborg et al, 2005; Aapro et al, 2008a; Strauss et al, 2008 & $\begin{array}{l}\text { Study-level } \\
H R\end{array}$ & 1.04 & $0.94-1.15$ \\
\hline 16 & Engert, 2007; Osterborg et al, 2005; Aapro et al, 2008a; Strauss et al, 2008 & $\begin{array}{l}\text { Patient-level } \\
\text { HR }\end{array}$ & 1.03 & $0.95-1.11$ \\
\hline
\end{tabular}

Abbreviations: $\mathrm{Cl}=$ confidence interval; $\mathrm{HR}=$ hazard ratio; $\mathrm{OR}=$ odds ratio. ${ }^{\mathrm{a}} \mathrm{ORs}$ were calculated for 20 studies with long-term follow-up data, for $\mathrm{I} 6$ studies where primary data were available and for 18 studies with either a reported or calculated HR. The OR was based only on the number of deaths. ${ }^{b} \mathrm{HRs}$ were calculated for 16 studies where primary data were available. Both study-level and patient-level analyses are provided.

employed varied. Only one study (AMG 20010145) (Pirker et al, 2008) rigorously assessed tumour progression radiographically using blinded centralised review. This small-cell lung cancer study in which all patients received the same chemotherapy regimen, reported that ESAs had no significant effect on disease progression (Pirker et al, 2008). In the remaining 25 studies, tumour progression was evaluated by the investigator (23 studies), by histopathology of tumour response (Amgen, 2007) or by radiographic assessment without central review (Grote et al, 2005).

To examine the effect of ESA use on disease progression in these 26 studies (9646 patients) and to standardise the variable outcome measures used to evaluate disease progression, ORs (ESA vs control) were calculated for each study (Figure 2B). Only the random-effects model was used since the many different disease progression estimates used in these studies would be expected to contribute to variability in the results. In the present meta-analysis, results indicated that ESA use was associated with a non-significant effect on disease progression (overall OR $=1.01$; 95\% CI: $0.90-1.14$; $I^{2}=29.4 \%$ ) (Figure 2B). When the 21 chemotherapy studies (7908 patients with 4053 ESA-treated patients and 3855 control patients) that evaluated disease progression were meta-analysed, the result also indicated a non-significant effect of ESA use on disease progression ( $\mathrm{OR}=0.95 ; 95 \% \mathrm{CI}$ : $0.85-1.06 ; I^{2}=2.3 \%$ ).

\section{VTE risk}

An increased risk for VTEs with ESA use has been observed in individual, randomised controlled ESA studies and is consistently reported in the meta-analyses of ESA oncology trials (Table 4). The current meta-analysis examined 44 studies (13 196 patients) that reported the incidence of VTEs in the settings of chemotherapy ( 35 studies), AoC (6 studies) and radiotherapy only (3 studies). Results revealed that the risk of VTEs was increased in ESA-treated patients $\left(\mathrm{OR}=1.48 ; 95 \% \mathrm{CI}: 1.28-1.72 ; I^{2}=0 \%\right.$; results were the same using either a random- or fixed-effects model) (Figure 3; Table 4). A similar result was seen when the 35 chemotherapy studies were analysed $\left(\mathrm{OR}=1.48 ; 95 \% \mathrm{CI}: 1.27-1.72 ; I^{2}=0 \%\right)$. A meta-analysis for VTE risk carried out in the 18 chemotherapy studies with long-term follow-up (6498 patients with 3859 ESAtreated patients and 2639 control patients; these studies were analysed as their reported VTE definitions were the most consistent) also indicated an increased VTE risk with ESA use $\left(\mathrm{OR}=1.47 ; 95 \% \mathrm{CI}: 1.24-1.74 ; I^{2}=0 \%\right.$; results were the same using either a random- or fixed-effects model).

\section{DISCUSSION}

The present meta-analysis of studies in the chemotherapy, radiotherapy and AoC oncology settings indicates that ESA use is associated with a significant increase in VTE risk (44 studies examined), but does not demonstrate a significant effect on mortality (60 studies examined) or on disease progression (26 studies examined). However, the US and EU ESA-labelling information describes how increased mortality and/or disease progression has been observed in 8 individual studies included in this meta-analysis: 4 in the chemotherapy setting (Hedenus et al, 2003; Leyland-Jones et al, 2005; Amgen, 2007; Thomas et al, 2008), 2 in the radiotherapy setting (Henke et al, 2003; Overgaard et $a l, 2007$ ) and 2 in the AoC setting (Wright et al, 2007; Smith et al, 2008). The current EU and US ESA-labelling information recommends that ESAs not be used in AoC or radiotherapy alone settings and that ESA therapy be initiated in patients with a baseline haemoglobin $\leqslant 10 \mathrm{~g} \mathrm{dl}^{-1}$ (EU) or $<10 \mathrm{~g} \mathrm{dl}^{-1}$ (US).

Three other large study-level meta-analyses have also shown that ESA use has a non-significant effect on survival in oncology patients (Bohlius et al, 2006; Ross et al, 2006; Seidenfeld et al, 2006) (Table 2). In contrast, the recent meta-analysis by Bennett et al (2008b) indicated that ESA-treated patients had significantly increased mortality (Table 2). The discrepancy between this finding and the findings from other meta-analyses, including this study, may be because of differences in the data or studies included for analysis (Bohlius et al, 2008). The present metaanalysis included all 51 studies used in the Bennett et al (2008b) study. However, a few studies included in the current analysis were not included in the Bennett et al (2008b) meta-analysis (Bennett et al, 2008b) or in a subsequent analysis performed by Bennett et al (2008a) that was described in a letter to the editor. In addition, this study included updated data (available either in recent publications or in unpublished study updates) not available to Bennett et al (2008b).

Of further interest, two meta-analyses examining the effect of ESA use on mortality in cancer patients were published after the present meta-analysis was completed. One was a patient-level meta-analysis carried out by the Cochrane EPO Individual Patient Data (IPD) Meta-analysis Collaborative group (data were supplied by Amgen, Centocor Ortho Biotech, Hoffman-La Roche and several large investigator-initiated studies) (Bohlius et al, 2009) and the other was a study-level meta-analysis carried out by the Canadian Agency for Drugs and Technologies in Health (Tonelli et al, 2009). In the Bohlius et al (2009) study, an analysis of chemotherapy studies (38 studies with 10441 patients) indicated that the overall-survival HR was 1.04 (95\% CI: 0.97-1.11) and the HR for deaths on study was 1.10 (95\% CI: 0.98-1.24) (Bohlius et al, 2009). In all oncology settings (53 trials with 13933 patients), the HR for overall survival was 1.06 (95\% CI: $1.00-1.12)$ and the HR for on-study mortality was 1.17 (95\% CI: $1.06-1.30$ ). Though the overall-survival HR for all oncology settings is nearly identical 
60 controlled ESA studies evaluated survival:

47 chemotherapy studies 9 AoC studies

4 radiotherapy only studies

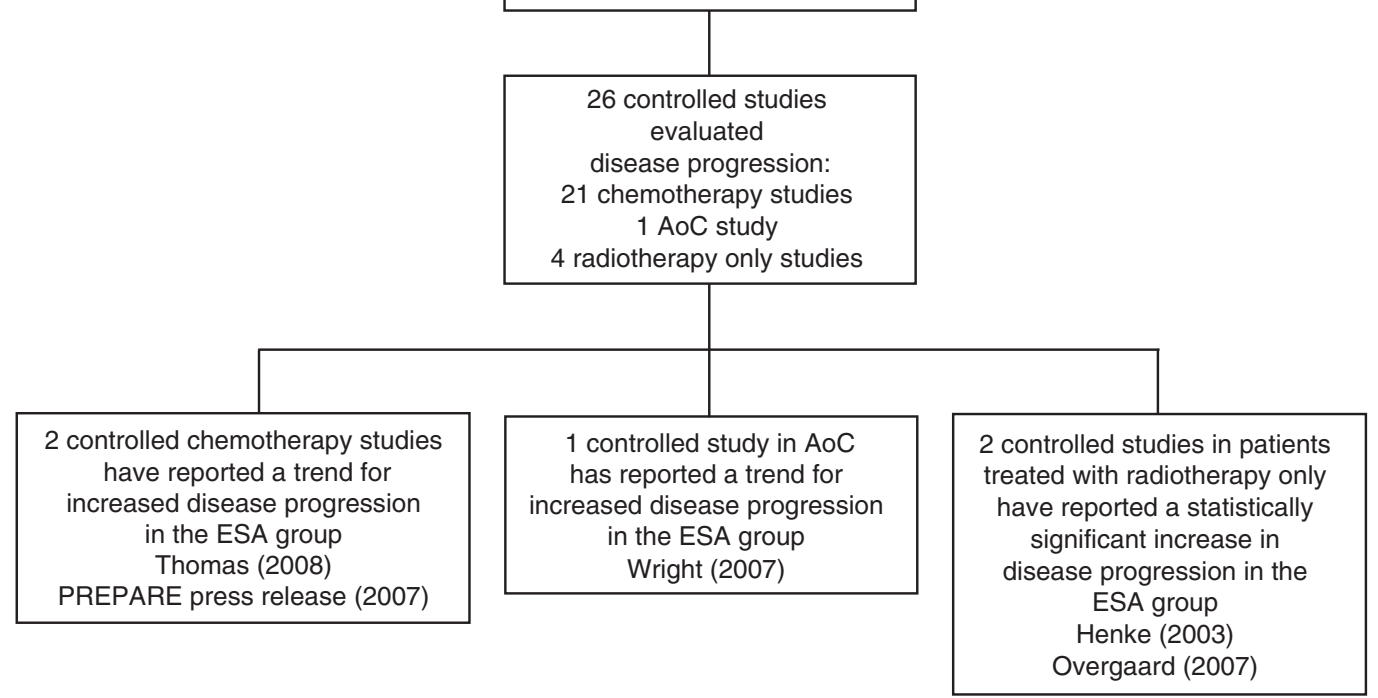

B

Study name

Vansteenkiste 2002

Blohmer 2004

* Littlewood 2001

* Osterborg 2005

* Chang 2005

Leyland-Jones 2005

* Grote 2005

Engert 2007

Strauss 2008

Pirker 2008

* Milroy 2003

* Vadhan-Raj 2004

Thomas 2008

* Pronzato 2002

EPO-GBR-7

Moebus 2007

Machtay 2007

Aapro 2008a

Hedenus 2003

Wright 2007

* Witzig 2005

* Osterborg 1996

PREPARE

Henke 2003

Overgaard 2007

* Wilkinson 2006

Random effects model
$95 \% \mathrm{Cl}$

Odds
ratio limit

$\begin{array}{lll}0.58 & 0.30 & 1.11\end{array}$

$\begin{array}{lll}0.61 & 0.33 & 1.13\end{array}$

$\begin{array}{lll}0.64 & 0.40 & 1.02\end{array}$

$\begin{array}{lll}0.74 & 0.44 & 1.25\end{array}$

$\begin{array}{lll}0.82 & 0.39 & 1.72\end{array}$

$\begin{array}{lll}0.84 & 0.64 & 1.08\end{array}$

$\begin{array}{lll}0.85 & 0.50 & 1.44\end{array}$

$\begin{array}{lll}0.86 & 0.33 & 2.24\end{array}$

$\begin{array}{lll}0.87 & 0.32 & 2.33\end{array}$

$\begin{array}{lll}0.87 & 0.52 & 1.46\end{array}$

$\begin{array}{lll}0.90 & 0.57 & 1.41\end{array}$

$\begin{array}{lll}1.01 & 0.35 & 2.94\end{array}$

$\begin{array}{lll}1.02 & 0.48 & 2.15\end{array}$

$\begin{array}{lll}1.02 & 0.46 & 2.26\end{array}$

$\begin{array}{lll}1.02 & 0.65 & 1.62\end{array}$

$\begin{array}{lll}1.05 & 0.75 & 1.48\end{array}$

$\begin{array}{lll}1.05 & 0.55 & 2.00\end{array}$

$\begin{array}{lll}1.07 & 0.82 & 1.40\end{array}$

$\begin{array}{lll}1.08 & 0.66 & 1.76\end{array}$

$\begin{array}{lll}1.08 & 0.30 & 3.95\end{array}$

$\begin{array}{lll}1.20 & 0.75 & 1.91\end{array}$

$\begin{array}{lll}1.20 & 0.60 & 2.40\end{array}$

$\begin{array}{lll}1.36 & 0.97 & 1.91\end{array}$

$\begin{array}{lll}1.56 & 1.01 & 2.39\end{array}$

$\begin{array}{lll}1.77 & 1.25 & 2.52\end{array}$

$\begin{array}{lll}7.47 & 0.95 & 58.54\end{array}$

$\begin{array}{lll}1.01 & 0.90 & 1.14\end{array}$

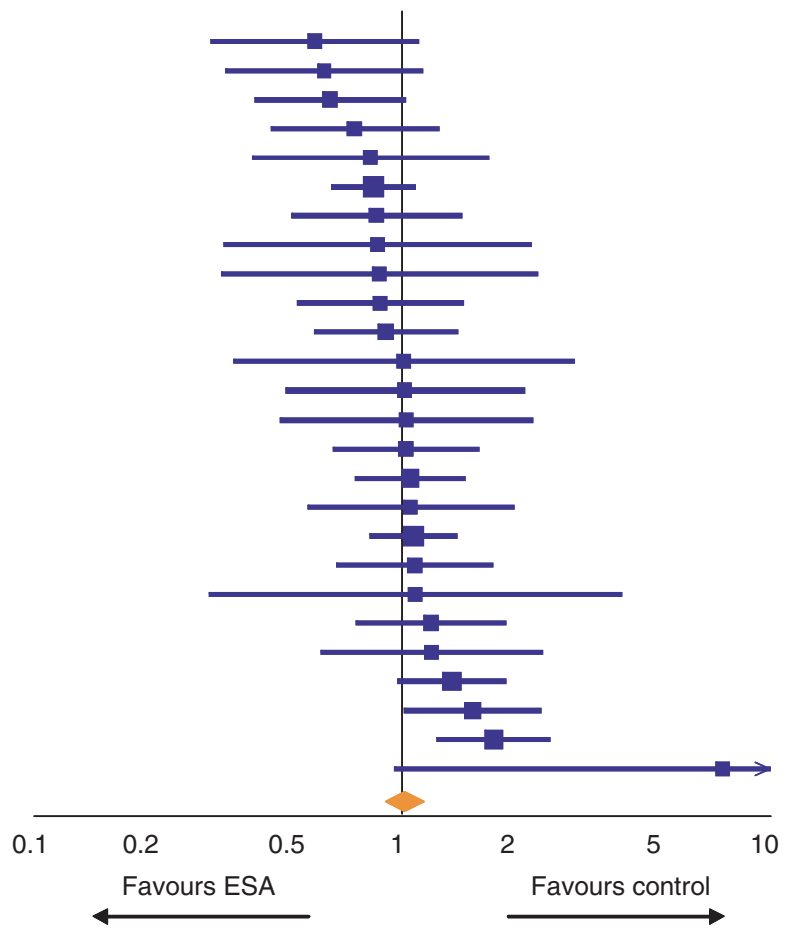

Figure 2 Effect of erythropoiesis-stimulating agent (ESA) use on disease progression. (A) Flow diagram of studies analysed. Of the 60 controlled ESA studies that measured survival, 26 also measured a disease-progression outcome. AoC indicates anaemia of cancer. (B) Study-level meta-analysis of disease progression-related endpoints in 26 controlled studies carried out in the settings of chemotherapy, AoC or radiotherapy only. This analysis included 9646 patients, with 4905 ESA-treated patients and 472I control patients. An asterisk denotes studies where disease progression was evaluated only as part of tumour assessment.

to the mortality OR estimated in the current meta-analysis, the HR for on-study mortality reported by Bohlius et al (2009) for all oncology settings indicated an increased risk of death with ESA use. Differences between results reported by Bohlius et al (2009) and results described here may reflect slight differences in the methods and data used. The Bohlius et al (2009) study used a straight intention-to-treat approach, whereas the current metaanalysis used a modified intention-to-treat approach when data were available for such an approach (only patients who received at least one dose of study drug were analysed). In addition, although 
Table 4 Risk of venous thromboembolism for patients receiving ESAs compared with patients not receiving ESAs: results from five meta-analyses ${ }^{\mathrm{a}}$

\begin{tabular}{lcccc}
\hline Meta-analysis & Number of trials & Number of patients & Statistic for VTE risk & 95\% Confidence interval \\
\hline Present meta-analysis & 44 & 13196 & 1.48 OR & $1.28-1.72$ \\
Bohlius et al, 2006 & 35 & 6769 & $1.67 \mathrm{RR}$ & $1.35-2.06$ \\
Seidenfeld et al, 2006 & 31 & 6412 & $1.68 \mathrm{RR}$ & $1.36-2.08$ \\
Ross et al, 2006 & 6 & 1463 & $1.41 \mathrm{OR}$ & $0.81-2.47$ \\
Bennett et al, 2008b & 38 & 8172 & $1.57 \mathrm{RR}$ & $1.31-1.87$ \\
\hline
\end{tabular}

Abbreviations: $\mathrm{ESA}=$ erythropoiesis-stimulating agent; $\mathrm{OR}=$ odds ratio; $\mathrm{RR}=$ relative risk; $\mathrm{VTE}=$ venous-thromboembolic event. ${ }^{\mathrm{a}}$ Results from studies conducted in the chemotherapy, radiotherapy and anaemia of cancer (AoC) settings are included.

\begin{tabular}{|c|c|c|c|c|}
\hline & & & & $\% \mathrm{Cl}$ \\
\hline Treatment type & Study name & $\begin{array}{c}\text { Odds } \\
\text { ratio }\end{array}$ & $\begin{array}{c}\text { Lower } \\
\text { limit }\end{array}$ & $\begin{array}{l}\text { Upper } \\
\text { limit }\end{array}$ \\
\hline AoC & Smith 2003 & 0.49 & 0.08 & 3. \\
\hline & Wright 2007 & 0.73 & 0.11 & 4. \\
\hline & Smith 2008 & 1.58 & 0.62 & 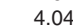 \\
\hline & Abels 1993 & 2.77 & 0.11 & 69.2 \\
\hline & Gordon 2006 & 3.06 & 0.16 & 57.68 \\
\hline & Charu 2007 & 4.63 & 0.26 & 81. \\
\hline Random effe & $\mathrm{AOC}$ & 1.36 & 0.68 & \\
\hline Radiotherapy only & Henke 2003 & 1.62 & 0.57 & \\
\hline & EPO-GBR-7 & 1.70 & 0.28 & 10. \\
\hline & Machtay 2007 & 6.72 & 0.34 & 132. \\
\hline Random effe & radiotherapy only & 1.84 & 0.78 & \\
\hline Chemotherapy & Bamias 2003 & 0.33 & 0.01 & \\
\hline & Blohmer 2004 & 0.34 & 0.03 & \\
\hline & Henry 1995 & 0.70 & 0.23 & \\
\hline & Case 1993 & 0.94 & 0.23 & \\
\hline & Grote 2005 & 0.97 & 0.52 & \\
\hline & Razzouk 2006 & 0.98 & 0.52 & \\
\hline & Kotasek 2003 & 1.03 & 0.40 & \\
\hline & Littlewood 2001 & 1.05 & 0.44 & \\
\hline & Leyland-Jones 2005 & 1.17 & 0.81 & 1. \\
\hline & Chang 2005 & 1.27 & 0.74 & \\
\hline & Debus 2006 & 1.44 & 0.81 & \\
\hline & Vansteenkiste 2002 & 1.46 & 0.45 & \\
\hline & EPO-INT-1 & 1.47 & 0.15 & 14. \\
\hline & Engert 2007 & 1.48 & 0.74 & \\
\hline & Taylor 2005 & 1.48 & 0.67 & \\
\hline & Witzig 2005 & 1.60 & 0.51 & \\
\hline & Pirker 2008 & 1.77 & 0.92 & \\
\hline & Moebus 2007 & 1.86 & 1.12 & \\
\hline & PREPARE & 1.92 & 0.91 & \\
\hline & Hedenus 2003 & 2.00 & 0.73 & \\
\hline & Hedenus 2002 & 2.01 & 0.10 & 40. \\
\hline & Aapro 2008a & 2.41 & 1.22 & \\
\hline & Thatcher 1999 & 2.63 & 0.12 & 56. \\
\hline & Thomas 2008 & 2.87 & 0.85 & \\
\hline & Throuvalas 2000 & 2.89 & 0.11 & 74. \\
\hline & Osterborg 2005 & 3.07 & 0.12 & 75. \\
\hline & Savonije 2005 & 3.53 & 0.43 & 29. \\
\hline & Strauss 2008 & 3.63 & 0.14 & 91. \\
\hline & Osterborg 1996 & 3.75 & 0.19 & 73. \\
\hline & EPO-INT-3 & 4.03 & 0.49 & 32. \\
\hline & Wilkinson 2006 & 5.32 & 0.66 & 42. \\
\hline & Ten Bokkel 1998 & 5.34 & 0.29 & \\
\hline & Dammacco 2001 & 5.86 & 0.67 & 51.46 \\
\hline & Vadhan-Raj 2004 & 8.18 & 0.92 & 72. \\
\hline & Goss 2005 & 9.40 & 2.58 & \\
\hline Random & del: chemotherapy & 1.48 & 1.27 & \\
\hline Random effe & overall & 1.48 & 1.28 & \\
\hline
\end{tabular}

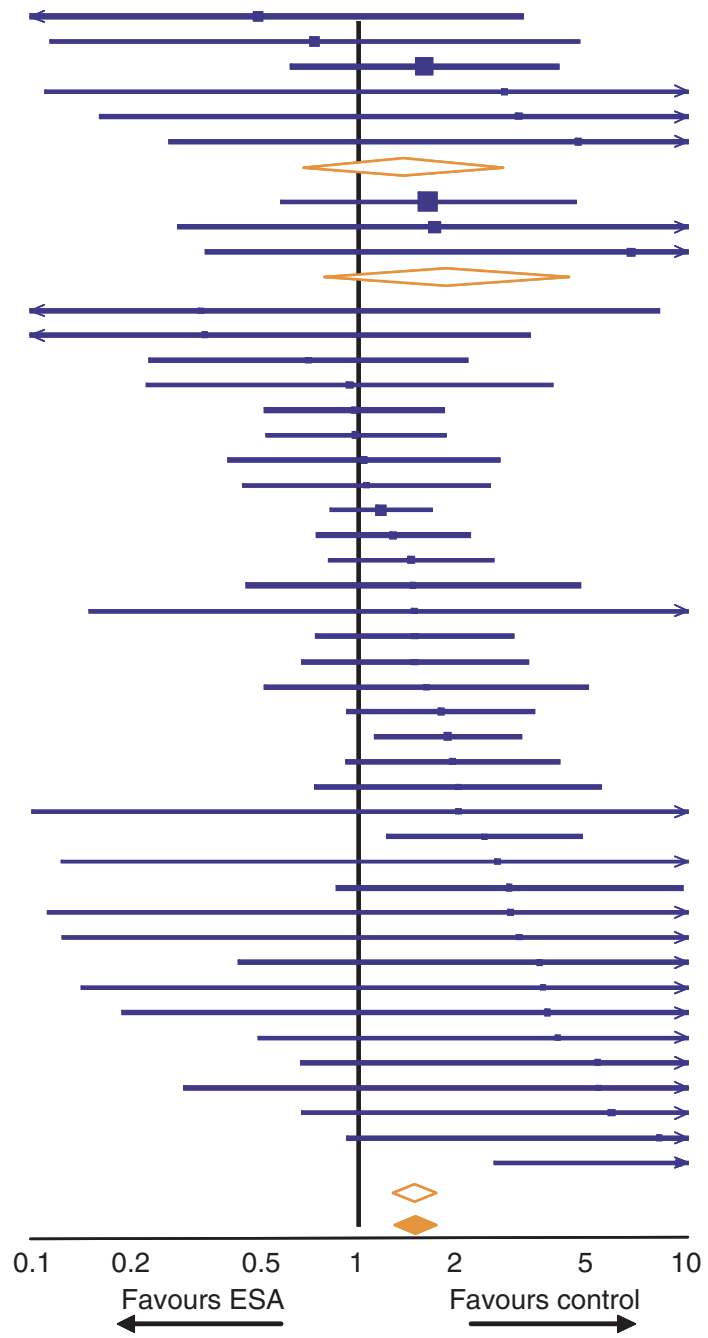

Figure 3 Study-level meta-analyses of venous-thromboembolic event (VTE) risk in 44 controlled studies carried out in the settings of chemotherapy, anaemia of cancer (AoC) or radiotherapy only. This analysis included 13196 patients with 7237 ESA-treated patients and 5959 control patients.

the Bohlius et al (2009) meta-analysis used patient-level data, the current meta-analysis only had access to published study-level data for those trials or investigator-sponsored studies sponsored by Hoffman-La Roche.

Similar to the current meta-analysis, the Tonelli et al (2009) metaanalysis indicated a non-significant effect of ESA use on mortality when 23 controlled trials (4273 patients) conducted in the chemotherapy setting were examined (relative risk $=1.04$; $95 \% \mathrm{CI}$ :
0.86-1.26) (Tonelli et al, 2009). However, an analysis of 28 controlled ESA trials (6525 patients) in all oncology settings indicated that ESA use was associated with a higher relative risk for mortality (relative risk $=1.15$; 95\% CI: 1.03-1.29) (Tonelli et al, 2009). Differences in the results reported by Tonelli et al (2009) and by the current metaanalysis may reflect differences in the studies analysed. Unlike the current meta-analysis, the Tonelli et al (2009) meta-analysis included publications written in a foreign language and studies conducted in a 
peri-surgical setting. In addition, the Tonelli et al (2009) metaanalysis did not include some key ESA trials (such as the BEST study by Leyland-Jones et al, 2005), as anaemia due to chemotherapy was not a study entry criterion.

Inconsistent results have also been reported across individual ESA studies with regard to when an ESA-associated mortality signal arises and in what tumour type it occurs. In chemotherapy studies with high haemoglobin targets $\left(\geqslant 12 \mathrm{~g} \mathrm{dl}^{-1}\right)$, decreases in survival have been observed both during the treatment period (e.g., in the first 4 months in the BEST study) (Leyland-Jones et al, 2005) and only after years of follow-up (ODAC, 2008; Hedenus et al, 2003 and Amgen, data on file). For every study listed in the US ESA-labelling information reporting an ESA-associated increase in mortality and/or disease progression in a specific tumour type (Amgen, 2009; Ortho, 2009), there is a study conducted in a similar tumour type that did not report these safety signals. For example, in cervical cancer, the GOG-0191 study (in 114 radiochemotherapy patients out of a planned 460) showed a nonsignificant trend of increased disease progression and increased mortality in ESA-treated patients at 3 years (Thomas et al, 2008). In contrast, a similar study in cervical cancer (250 radiochemotherapy patients) showed no difference in the overall survival between treatment arms after 4.8 years of follow-up (Blohmer et al, 2004). In breast cancer, an unplanned analysis of 3-year interim data from the Preoperative Epirubicin Paclitaxel Aranesp (PREPARE) study (733 chemotherapy patients) reported increased mortality and increased disease progression in ESAtreated patients (Amgen, 2007). However, final 5-year follow-up results from another breast cancer study (643 chemotherapy patients) showed no survival difference between treatment groups (Moebus et al, 2007). Inconsistent safety signals have also been observed in other cancer types, most notably haematological malignancies (Osterborg et al, 1996, 2005; Hedenus et al, 2003). The current EU and US ESA-labelling information contain no restrictions on ESA use by tumour type (EMEA, 2008; eMC, 2008; Amgen, 2009; Ortho, 2009).

The mechanism behind the ESA-associated increase in mortality seen in some studies is unclear. One hypothesised mechanism is that ESAs could stimulate disease progression by activating erythropoietin receptors (EpoRs) that might be present on tumour cells and/or tumour-associated vasculature. Several immunohistochemistry studies using polyvalent rabbit anti-sera raised against EpoR (i.e., polyclonal antibodies for EpoR) have reported EpoR expression in some primary human tumours and endothelial cells (reviewed in Osterborg et al, 2007; Sinclair et al, 2007). Several studies have also reported that recombinant human erythropoietin might have a proliferative or survival-promoting effect on tumours (Takeshita et al, 2000; Westenfelder and Baranowski, 2000; Acs et al, 2001; Lai et al, 2005; Feldman et al, 2006). However, the majority of pre-clinical studies have failed to detect such effects when human tumour cell lines (in cell culture or in rodent tumour models) are exposed to ESAs, even at suprapharmacological ESA concentrations (Osterborg et al, 2007; Sinclair et al, 2007). Furthermore, several investigators have independently demonstrated that commercially available EpoR antibodies lack specificity and provide false-positive results with immunohistochemistry (Elliott et al, 2006; Brown et al, 2007; Sinclair et al, 2007; Laugsch et al, 2008). Recent studies have also found that tumour cell lines and tumour biopsies do not contain increased levels of EpoR mRNA transcripts compared with normal tissue controls and that the EpoR gene is not amplified in tumour cells (Sinclair et al, 2008). Overall, the weight of preclinical evidence does not support a role for EpoR in tumour growth. A recent workshop at the National Cancer Institute (December 2007) concluded that conflicting and confounding data exist regarding the expression and function of EpoR protein on tumour cells and the association of EpoR with disease progression. Additional research with more specific
EpoR-detection agents is needed to examine questions regarding EpoR and disease progression.

Examining ESA use and disease progression is further complicated by the fact that disease progression has not been a primary or secondary endpoint in most oncology ESA studies. In addition, great variation exists in the progression endpoints measured (e.g., progression-free survival, tumour response, local-regional relapse, and so on) and in the quality, consistency and frequency of tumour assessments. Further, only those chemotherapy studies targeting high haemoglobin levels $\left(\geqslant 12 \mathrm{~g} \mathrm{dl}^{-1}\right)$ have reported increased mortality with ESA use. If an ESA-associated mortality risk is due to increased disease progression, then this mortality risk would be expected to be observed regardless of the target haemoglobin level. Additional controlled studies are needed that prespecify disease progression as a primary or secondary endpoint and that use consistent methods with central review to collect and report the diseaseprogression data.

Though an ESA-associated mortality signal in the chemotherapy setting is only seen in studies targeting a high haemoglobin level $\left(\geqslant 12 \mathrm{~g} \mathrm{dl}^{-1}\right)$, not all such chemotherapy studies have reported this signal (Pirker et al, 2008). Thus, the mechanism responsible for ESA-associated mortality is unlikely to be solely related to the high haemoglobin target. An exploratory analysis of six controlled darbepoetin alfa chemotherapy trials indicated that patients who responded poorly to ESA therapy (i.e., haemoglobin levels rose very little or not at all; $n=1089$ ) had a two-fold higher mortality rate relative to patients who responded well to ESA therapy $(n=385)$ (Amgen, data on file). Though poor ESA responders appeared to drive the mortality signal in these chemotherapy studies, reasons for the increased mortality were unclear. This finding is notably confounded in that a poor response to ESA therapy may be a marker for those patients with a poorer prognosis (ODAC, 2008). The current ESA-labelling information recommends halting ESAs in cancer patients who have no haemoglobin response.

Poor ESA response as a driver for a mortality signal in studies with high haemoglobin target has also been observed in the nephrology setting. In both the Normal Hematocrit Cardiac Trial (NHCT) (Besarab et al, 1998) and the Correction of Hemoglobin in the Outcomes in Renal Insufficiency (CHOIR) trial (Singh et al, 2006), patients randomised to arms with higher haemoglobin targets had an elevated risk for a composite event of cardiovascular hospitalisation and death. However, those patients who achieved higher haemoglobin levels in both the lower haemoglobin-target arms and the higher haemoglobin-target arms had better outcomes. A re-analysis of data from the NHCT higher haemoglobin-target arm showed that patients with the lowest haemoglobin response had the highest mortality risk, which was independent of other mortality predictors (Kilpatrick et al, 2008).

The well-characterised risk of VTEs associated with ESA use has been posed as a possible mechanism for the ESA-associated mortality observed in some ESA studies. An increased VTE risk with ESA use in the oncology setting is documented in the scientific literature (Bohlius et al, 2006), in the US ESA-labelling information (Amgen, 2007; Ortho, 2009), and is also supported by the present meta-analysis. If poor ESA response drives the mortality signal and the mechanism for increased mortality is VTE incidence, the implication is that ESA exposure can increase VTE risk by a mechanism unrelated to haemoglobin rise, as poor responders show little or no increase in haemoglobin. An alternate mechanism could be an effect of ESAs on Virchow's triad of factors that affect the pathogenesis of thrombosis, including hypercoagulability, vessel-wall injury and venous stasis (Baron et al, 1998; Lee, 2002). Studies examining survival in ESA-treated cancer patients treated with prophylactic low-molecular-weight heparin (to decrease VTEs) (Geerts et al, 2004) would be enlightening. 
Studies are needed to further explore the effect of ESA use on survival and disease progression, to definitively determine what can drive ESA-associated mortality, and to evaluate factors that may identify patients most at risk for increased mortality with ESA use. Important information will be provided from ongoing clinical trials such as the PREPARE trial and the EPO-ANE-3010 trial, which is an open-label, randomised and controlled trial in metastatic breast cancer patients measuring progression-free survival (primary endpoint) and overall survival (secondary endpoint) (Centocor Ortho Biotech, data on file). A large, placebo-controlled, non-inferiority study in non-small-cell lung cancer has been proposed in which randomisation will be stratified by prognostic factors (study 20070782; Amgen, data on file) and overall survival (primary endpoint) and progression-free survival (secondary endpoint) will be examined. Results from these and additional trials and from inclusive meta-analyses will provide important evidence to inform evidence-based decision making.

\section{ACKNOWLEDGEMENTS}

We thank Linda Runft, $\mathrm{PhD}$, and Sadie Whittaker, $\mathrm{PhD}$, at Amgen, for assistance in the writing of this manuscript.

\section{REFERENCES}

Aapro M, Coiffier B, Dunst J, Osterborg A, Burger HU (2006) Effect of treatment with epoetin beta on short-term tumour progression and survival in anaemic patients with cancer: a meta-analysis. Br J Cancer 95: $1467-1473$

Aapro M, Leonard RC, Barnadas A, Marangolo M, Untch M, Malamos N, Mayordomo J, Reichert D, Pedrini JL, Ukarma L, Scherhag A, Burger HU (2008a) Effect of once-weekly epoetin beta on survival in patients with metastatic breast cancer receiving anthracycline- and/or taxane-based chemotherapy: results of the Breast Cancer-Anemia and the Value of Erythropoietin (BRAVE) study. J Clin Oncol 26: 592-598

Aapro M, Scherhag A, Burger HU (2008b) Effect of treatment with epoetinbeta on survival, tumour progression and thromboembolic events in patients with cancer: an updated meta-analysis of 12 randomised controlled studies including 2301 patients. $\mathrm{Br}$ J Cancer 99: 14-22

Abels R (1993) Erythropoietin for anaemia in cancer patients. Eur J Cancer 29A(Suppl 2): S2 - S8

Acs G, Acs P, Beckwith SM, Pitts RL, Clements E, Wong K, Verma A (2001) Erythropoietin and erythropoietin receptor expression in human cancer. Cancer Res 61: $3561-3565$

Amato A, Pescatori M (2006) Perioperative blood transfusions for the recurrence of colorectal cancer. Cochrane Database Syst Rev 25(1): CD005033

Amgen (2007) Amgen announces interim results of Aranesp ${ }^{\circledR}$ 'PREPARE' study in breast cancer patients (Amgen press release). Nov 30, 2007; Available from: http://wwwext.amgen.com/media/media_pr_detail.jsp? year $=2007 \&$ releaseID $=1083091 \quad$ [Accessed February 29, 2008]

Amgen (2009) Aranesp ${ }^{\circledR}$ (Darbepoetin alfa) Package Insert. Amgen Inc., Thousand Oaks, CA

Auerbach M, Ballard H, Trout JR, McIlwain M, Ackerman A, Bahrain H, Balan S, Barker L, Rana J (2004) Intravenous iron optimizes the response to recombinant human erythropoietin in cancer patients with chemotherapy-related anemia: a multicenter, open-label, randomized trial. J Clin Oncol 22: $1301-1307$

Bamias A, Aravantinos G, Kalofonos C, Timotheadou N, Siafaka V, Vlahou I, Janinis D, Pectasides D, Pavlidis N, Fountzilas G (2003) Prevention of anemia in patients with solid tumors receiving platinum-based chemotherapy by recombinant human erythropoietin (rHuEpo): a prospective, open label, randomized trial by the Hellenic Cooperative Oncology Group. Oncology 64: $102-110$

Barbara JA (2004) The rationale for pathogen-inactivation treatment of blood components. Int J Hematol 80: $311-316$

Baron JA, Gridley G, Weiderpass E, Nyren O, Linet M (1998) Venous thromboembolism and cancer. Lancet 351: 1077-1080

Bastit L, Vandebroek A, Altintas S, Gaede B, Pinter T, Suto TS, Mossman TW, Smith KE, Vansteenkiste JF (2008) Randomized, multicenter, controlled trial comparing the efficacy and safety of darbepoetin alpha administered every 3 weeks with or without intravenous iron in patients with chemotherapy-induced anemia. J Clin Oncol 26: $1611-1618$

Bennett CL, Henke M, Lai SY (2008a) Erythropoiesis-stimulating agents in the treatment of cancer-associated anemia - Reply. JAMA 300: $2855-2857$

Bennett CL, Silver SM, Djulbegovic B, Samaras AT, Blau CA, Gleason KJ, Barnato SE, Elverman KM, Courtney DM, McKoy JM, Edwards BJ, Tigue CC, Raisch DW, Yarnold PR, Dorr DA, Kuzel TM, Tallman MS, Trifilio SM, West DP, Lai SY, Henke M (2008b) Venous thromboembolism and mortality associated with recombinant erythropoietin and darbepoetin administration for the treatment of cancer-associated anemia. JAMA 299: 914- 924

Besarab A, Bolton WK, Browne JK, Egrie JC, Nissenson AR, Okamoto DM, Schwab SJ, Goodkin DA (1998) The effects of normal as compared with low hematocrit values in patients with cardiac disease who are receiving hemodialysis and epoetin. N Engl J Med 339: 584-590

Blohmer J-U, Wurschmidt F, Petry U, Weise G, Sehouli J, Kimming R, Dressler P, Kentenich H, Kohls A, Lichtenegger W (2004) Results with sequential adjuvant chemo-radiotherapy with vs without epoetin alfa for patients with high-risk cervical cancer: results of a prospective, randomized, open and controlled AGO- and NOGGO-intergroup study. Ann Oncol 15: Abstract 477PD

Bohlius J, Engert A, Schwarzer G (2008) Erythropoiesis-stimulating agents in the treatment of cancer-associated anemia. JAMA 300: 2854-2855; author reply 2855-2857

Bohlius J, Langensiepen S, Schwarzer G, Seidenfeld J, Piper M, Bennett C, Engert A (2005) Recombinant human erythropoietin and overall survival in cancer patients: results of a comprehensive meta-analysis. J Natl Cancer Inst 97: 489-498

Bohlius J, Schmidlin K, Brillant C, Schwarzer G, Trelle S, Seidenfeld J, Zwahlen M, Clarke M, Weingart O, Kluge S, Piper M, Rades D, Steensma DP, Djulbegovic B, Fey MF, Ray-Coquard I, Machtay M, Moebus V, Thomas G, Untch M, Schumacher M, Egger M, Engert A (2009) Recombinant human erythropoiesis-stimulating agents and mortality in patients with cancer: a meta-analysis of randomised trials. Lancet 373: $1532-1542$

Bohlius J, Wilson J, Seidenfeld J, Piper M, Schwarzer G, Sandercock J, Trelle S, Weingart O, Bayliss S, Djulbegovic B, Bennett CL, Langensiepen S, Hyde C, Engert A (2006) Recombinant human erythropoietins and cancer patients: updated meta-analysis of 57 studies including 9353 patients. J Natl Cancer Inst 98: 708-714

Bokemeyer C, Aapro MS, Courdi A, Foubert J, Link H, Osterborg A, Repetto L, Soubeyran P (2007) EORTC guidelines for the use of erythropoietic proteins in anaemic patients with cancer: 2006 update. Eur J Cancer 43: $258-270$

Boogaerts M, Oberhoff C, Ten Bokkel Huinink W, Nowrousian MR, Hayward CR, Burger HU (2006) Epoetin beta (NeoRecormon) therapy in patients with solid tumours receiving platinum and non-platinum chemotherapy: a meta-analysis. Anticancer Res 26: 479-484

Brown WM, Maxwell P, Graham AN, Yakkundi A, Dunlop EA, Shi Z, Johnston PG, Lappin TR (2007) Erythropoietin receptor expression in non-small cell lung carcinoma: a question of antibody specificity. Stem Cells 25: $718-722$

Cascinu S, Fedeli A, Del Ferro E, Luzi Fedeli S, Catalano G (1994) Recombinant human erythropoietin treatment in cisplatin-associated anemia: a randomized, double-blind trial with placebo. J Clin Oncol 12: $1058-1062$

Case Jr DC., Bukowski RM, Carey RW, Fishkin EH, Henry DH, Jacobson RJ, Jones SE, Keller AM, Kugler JW, Nichols CR, Salmon SE, Silver RT, Storniolo AM, Wampler GL, Dooley CM, Larholt KM, Nelson RA, Abels RI (1993) Recombinant human erythropoietin therapy for anemic cancer patients on combination chemotherapy. J Natl Cancer Inst 85: $801-806$

Cazzola M, Messinger D, Battistel V, Bron D, Cimino R, Enller-Ziegler L, Essers U, Greil R, Grossi A, Jager G, LeMevel A, Najman A, Silingardi V, 
Spriano M, van Hoof A, Ehmer B (1995) Recombinant human erythropoietin in the anemia associated with multiple myeloma or non-Hodgkin's lymphoma: dose finding and identification of predictors of response. Blood 86: $4446-4453$

Cella D, Dobrez D, Glaspy J (2003) Control of cancer-related anemia with erythropoietic agents: a review of evidence for improved quality of life and clinical outcomes. Ann Oncol 14: 511-519

Chang J, Couture F, Young S, McWatters KL, Lau CY (2005) Weekly epoetin alfa maintains hemoglobin, improves quality of life, and reduces transfusion in breast cancer patients receiving chemotherapy. J Clin Oncol 23: $2597-2605$

Charu V, Belani CP, Gill AN, Bhatt M, Tomita D, Rossi G, Ben-Jacob A (2007) Efficacy and safety of every-2-week darbepoetin alfa in patients with anemia of cancer: a controlled, randomized, open-label phase II trial. Oncologist 12: $727-737$

Coiffier B, Boogaerts M, Kainz C, Group EBQW, Group EBPW (2001) Impact of epopetin beta versus standard care on quality of life in patients with malignant disease. Paper presented at: The 6th Annual Meeting of the European Haematology Association; June 21-24, 2001; Frankfurt, Germany

Curt GA, Breitbart W, Cella D, Groopman JE, Horning SJ, Itri LM, Johnson DH, Miaskowski C, Scherr SL, Portenoy RK, Vogelzang NJ (2000) Impact of cancer-related fatigue on the lives of patients: new findings from the Fatigue Coalition. Oncologist 5: 353-360

Dammacco F, Castoldi G, Rodjer S (2001) Efficacy of epoetin alfa in the treatment of anaemia of multiple myeloma. $\mathrm{Br}$ J Haematol 113: 172 - 179

Debus J, Hindermann S, Morr H, Mezger J, Sebastian M, Angermund R, Drings P (2006) Epoetin alfa (EPO) and survival in patients with nonresectable NSCLC - Interim results. Presented at the German Medical Sciences Meeting, Berlin 2006. Available from: http://www.egms.de/en/ meetings/dkk2006/06dkk257.shtml [Accessed 29 May 2008]

Del Mastro L, Venturini M, Lionetto R, Garrone O, Melioli G, Pasquetti W, Sertoli MR, Bertelli G, Canavese G, Costantini M, Rosso R (1997) Randomized phase III trial evaluating the role of erythropoietin in the prevention of chemotherapy-induced anemia. J Clin Oncol 15: $2715-2721$

Demetri GD, Kris M, Wade J, Degos L, Cella D (1998) Quality-of-life benefit in chemotherapy patients treated with epoetin alfa is independent of disease response or tumor type: results from a prospective community oncology study. Procrit Study Group. J Clin Oncol 16: $3412-3425$

Dunphy FR, Harrison BR, Dunleavy TL, Rodriguez JJ, Hilton JG, Boyd JH (1999) Erythropoietin reduces anemia and transfusions: a randomized trial with or without erythropoietin during chemotherapy. Cancer 86: $1362-1367$

Egger M, Smith GD, Phillips AN (1997) Meta-analysis: principles and procedures. BMJ 315: $1533-1537$

Elliott S, Busse L, Bass MB, Lu H, Sarosi I, Sinclair AM, Spahr C, Um M, Van G, Begley CG (2006) Anti-Epo receptor antibodies do not predict Epo receptor expression. Blood 107: 1892-1895

eMC (2008) electronic Medicines Compendium (eMC) website. Available from: http://emc.medicines.org.uk [Accessed October 29, 2008]

EMEA (2008) European public assessment reports for authorised medicinal products for human use. European Medicines Agency website. Available from: http://www.emea.europa.eu/htms/human/epar/a.htm [Accessed October 29, 2008]

Engert A (2007) On behalf of the German Hodgkin Study Group. Role of erythropoetin (EPO) in patients with Hodgkin lymphoma. Paper presented at The 7th International Symposium on Hodgkin Lymphoma; November 3-7, 2007; Cologne, Germany

Feldman L, Wang Y, Rhim JS, Bhattacharya N, Loda M, Sytkowski AJ (2006) Erythropoietin stimulates growth and STAT5 phosphorylation in human prostate epithelial and prostate cancer cells. Prostate 66: $135-145$

Gabrilove JL, Cleeland CS, Livingston RB, Sarokhan B, Winer E, Einhorn LH (2001) Clinical evaluation of once weekly dosing of epoetin alfa in chemotherapy patients: improvements in hemoglobin and quality of life are similar to three-times weekly dosing. J Clin Oncol 19: $2875-2882$

Geerts WH, Pineo GF, Heit JA, Bergqvist D, Lassen MR, Colwell CW, Ray JG (2004) Prevention of venous thromboembolism: the Seventh ACCP Conference on Antithrombotic and Thrombolytic Therapy. Chest 126: $338 \mathrm{~S}-400 \mathrm{~S}$

Glaspy J, Bukowski R, Steinberg D, Taylor C, Tchekmedyian S, Vadhan-Raj $S$ (1997) Impact of therapy with epoetin alfa on clinical outcomes in patients with non-myeloid malignancies during cancer chemotherapy in community oncology practice. Procrit Study Group. I Clin Oncol 15: $1218-1234$

Gordon DH, Nichols G, Ben-Jacob A, Lam H, Lillie T, Miller C (2006) Treating anemia of cancer with darbepoetin alfa administered every 4 weeks: Final results from a phase 2, randomized, double-blind, placebocontrolled study in cancer patients not receiving chemotherapy and/or radiotherapy. Blood 108: Abstract 1304

Goss G, Feld R, Bezjak A, Perry G, Melosky B, Smith C, Snee M, Plante R, Lau C (2005) Impact of maintaining $\mathrm{Hb}$ with epoetin alfa on time to progression (TTP), overall survival (OS), quality of life (QOL), and transfusion reduction in limited disease SCLC patients. Lung Cancer 49: S53, Abstract O-154

Groopman JE, Itri LM (1999) Chemotherapy-induced anemia in adults: incidence and treatment. J Natl Cancer Inst 91: 1616-1634

Grote T, Yeilding AL, Castillo R, Butler D, Fishkin E, Henry DH, DeLeo M, Fink K, Sullivan DJ (2005) Efficacy and safety analysis of epoetin alfa in patients with small-cell lung cancer: a randomized, double-blind, placebo-controlled trial. J Clin Oncol 23: 9377-9386

Hedenus M, Adriansson M, San Miguel J, Kramer MH, Schipperus MR, Juvonen E, Taylor K, Belch A, Altes A, Martinelli G, Watson D, Matcham J, Rossi G, Littlewood TJ (2003) Efficacy and safety of darbepoetin alfa in anaemic patients with lymphoproliferative malignancies: a randomized, double-blind, placebo-controlled study. Br J Haematol 122: 394-403

Hedenus M, Hansen S, Taylor K, Arthur C, Emmerich B, Dewey C, Watson D, Rossi G, Osterborg A (2002) Randomized, dose-finding study of darbepoetin alfa in anaemic patients with lymphoproliferative malignancies. Br J Haematol 119: 79-86

Hedenus M, Vansteenkiste J, Kotasek D, Austin M, Amado RG (2005) Darbepoetin alfa for the treatment of chemotherapy-induced anemia: disease progression and survival analysis from four randomized, doubleblind, placebo-controlled trials. J Clin Oncol 23: 6941-6948

Henke M, Laszig R, Rube C, Schafer U, Haase KD, Schilcher B, Mose S, Beer KT, Burger U, Dougherty C, Frommhold H (2003) Erythropoietin to treat head and neck cancer patients with anaemia undergoing radiotherapy: randomised, double-blind, placebo-controlled trial. Lancet 362: $1255-1260$

Henry DH, Brooks Jr BJ., Case Jr DC., Fishkin E, Jacobson R, Keller AM, Kugler J, Moore J, Silver RT, Storniolo AM, Abels RI, Gordon DS, Nelson R, Larholt K, Bryant E, Rudnick S (1995) Recombinant human erythropoietin therapy for anemic cancer patients receiving cisplatin chemotherapy. Cancer J Sci Am 1: 252-260

Kilpatrick RD, Critchlow CW, Fishbane S, Besarab A, Stehman-Breen C, Krishnan M, Bradbury BD (2008) Greater epoetin alfa responsiveness is associated with improved survival in hemodialysis patients. Clin J Am Soc Nephrol 3: 1077-1083

Knight K, Wade S, Balducci L (2004) Prevalence and outcomes of anemia in cancer: a systematic review of the literature. Am J Med 116(Suppl 7A): $11 \mathrm{~S}-26 \mathrm{~S}$

Kotasek D, Steger G, Faught W, Underhill C, Poulsen E, Colowick AB, Rossi G, Mackey J (2003) Darbepoetin alfa administered every 3 weeks alleviates anaemia in patients with solid tumours receiving chemotherapy; results of a double-blind, placebo-controlled, randomised study. Eur J Cancer 39: 2026-2034

Kurz C, Marth C, Windbichler G, Lahousen M, Medl M, Vavra N, Sevelda P (1997) Erythropoietin treatment under polychemotherapy in patients with gynecologic malignancies: a prospective, randomized, double-blind placebo-controlled multicenter study. Gynecol Oncol 65: 461-466

Lai SY, Childs EE, Xi S, Coppelli FM, Gooding WE, Wells A, Ferris RL, Grandis JR (2005) Erythropoietin-mediated activation of JAK-STAT signaling contributes to cellular invasion in head and neck squamous cell carcinoma. Oncogene 24: $4442-4449$

Laugsch M, Metzen E, Svensson T, Depping R, Jelkmann W (2008) Lack of functional erythropoietin receptors of cancer cell lines. Int J Cancer 122: $1005-1011$

Lee AY (2002) Cancer and thromboembolic disease: pathogenic mechanisms. Cancer Treat Rev 28: 137-140

Leyland-Jones B, Semiglazov V, Pawlicki M, Pienkowski T, Tjulandin S, Manikhas G, Makhson A, Roth A, Dodwell D, Baselga J, Biakhov M, Valuckas K, Voznyi E, Liu X, Vercammen E (2005) Maintaining normal hemoglobin levels with epoetin alfa in mainly nonanemic patients with metastatic breast cancer receiving first-line chemotherapy: a survival study. J Clin Oncol 23: 5960-5972

Littlewood TJ, Bajetta E, Nortier JW, Vercammen E, Rapoport B (2001) Effects of epoetin alfa on hematologic parameters and quality of life in cancer patients receiving nonplatinum chemotherapy: results of a 
randomized, double-blind, placebo-controlled trial. J Clin Oncol 19: $2865-2874$

Looney MR, Gropper MA, Matthay MA (2004) Transfusion-related acute lung injury: a review. Chest 126: $249-258$

Ludwig H, Van Belle S, Barrett-Lee P, Birgegard G, Bokemeyer C, Gascon P, Kosmidis P, Krzakowski M, Nortier J, Olmi P, Schneider M, Schrijvers D (2004) The European Cancer Anaemia Survey (ECAS): a large, multinational, prospective survey defining the prevalence, incidence, and treatment of anaemia in cancer patients. Eur J Cancer 40: 2293-2306

Machtay M, Pajak TF, Suntharalingam M, Shenouda G, Hershock D, Stripp DC, Cmelak AJ, Schulsinger A, Fu KK (2007) Radiotherapy with or without erythropoietin for anemic patients with head and neck cancer: a randomized trial of the Radiation Therapy Oncology Group (RTOG 99-03). Int J Radiat Oncol Biol Phys 69: 1008-1017

Milroy R, Scagliotti G, van den Berg PM, Galanis NE, Gomez RG, Greil R, Krzakowski M (2003) Early intervention with epoetin alfa maintains hemoglobin (HB) in advanced non-small-cell lung cancer (NSCLC) patients. Lung Cancer 41: S74

Minton O, Stone P, Richardson A, Sharpe M, Hotopf M (2008) Drug therapy for the management of cancer related fatigue. Cochrane Database Syst Rev 23(1): CD006704

Moebus V, Lueck H, Thomssen C, Harbeck N, Nitz U, Kreienberg R, Jackisch C, Schneeweiss A, Huober J, du Bois A, Untch M (2007) The impact of epoetin-alpha on anemia, red blood cell (RBC) transfusions, and survival in breast cancer patients (pts) treated with dose-dense sequential chemotherapy: Mature results of an AGO phase III study (ETC trial). J Clin Oncol 25: Abstract 569

Mystakidou K, Kalaidopoulou O, Katsouda E, Parpa E, Kouskouni E, Chondros C, Tsiatas ML, Vlahos L (2005) Evaluation of epoetin supplemented with oral iron in patients with solid malignancies and chronic anemia not receiving anticancer treatment. Anticancer Res 25: $3495-3500$

O'Shaughnessy JA, Vukelja SJ, Holmes FA, Savin M, Jones M, Royall D, George M, Von Hoff D (2005) Feasibility of quantifying the effects of epoetin alfa therapy on cognitive function in women with breast cancer undergoing adjuvant or neoadjuvant chemotherapy. Clin Breast Cancer 5: $439-446$

Oberhoff C, Neri B, Amadori D, Petry KU, Gamucci T, Rebmann U, Nowrousian MR, Voigtmann R, Monfardini S, Armand JP, Herrmann R, Netter-Pinon J, Tubiana-Mathieu N, Zwierzina H (1998) Recombinant human erythropoietin in the treatment of chemotherapy-induced anemia and prevention of transfusion requirement associated with solid tumors: a randomized, controlled study. Ann Oncol 9: 255-260

ODAC (2008) Amgen Inc. in collaboration with Johnson \& Johnson Pharmaceutical Research and Development, L.L.C.Background Information. For The Oncologic Drugs Advisory Comittee (ODAC) Meeting 13 March 2008. Available from: http://www.fda.gov/ohrms/dockets/ac/08/ briefing/2008-4345b2-00-FDA-index.htm [Accessed March 21, 2008]

Ortho (2009) Procrit ${ }^{\mathbb{R}}$ (Epoetin alfa) Package Insert. Centocor Ortho Biotech Inc.: L.P., Raritan, NJ

Osterborg A, Aapro M, Cornes P, Haselbeck A, Hayward CR, Jelkmann W (2007) Preclinical studies of erythropoietin receptor expression in tumour cells: impact on clinical use of erythropoietic proteins to correct cancer-related anaemia. Eur J Cancer 43: 510-519

Osterborg A, Boogaerts MA, Cimino R, Essers U, Holowiecki J, Juliusson G, Jager G, Najman A, Peest D (1996) Recombinant human erythropoietin in transfusion-dependent anemic patients with multiple myeloma and non-Hodgkin's lymphoma-a randomized multicenter study. The European Study Group of Erythropoietin (Epoetin Beta) Treatment in Multiple Myeloma and Non-Hodgkin's Lymphoma. Blood 87: 2675-2682

Osterborg A, Brandberg Y, Hedenus M (2005) Impact of epoetin-beta on survival of patients with lymphoproliferative malignancies: longterm follow up of a large randomized study. Br J Haematol 129: 206-209

Overgaard J, Hoff C, Sand Hansen H, Specht L, Overgaard M, Grau C, Andersen E, Johansen J, Andersen L, Evensen J (2007) Randomized study of the importance of novel erythropoiesis stimulating protein (Aranesp ${ }^{\circledR}$ ) for the effect of radiotherapy in patients with primary squamous cell carcinoma of the head and neck (HNSCC)- the Danish Head and Neck Cancer Group DAHANCA 10 randomized trial. Eur J Cancer 4: 7 (Abstract 628)

Pangalis GA, Poziopoulos C, Angelopoulou MK, Siakantaris MP Panayiotidis P (1995) Effective treatment of disease-related anaemia in B-chronic lymphocytic leukaemia patients with recombinant human erythropoietin. Br J Haematol 89: 627-629
Pirker R, Ramlau RA, Schuette W, Zatloukal P, Ferreira I, Lillie T, Vansteenkiste JF (2008) Safety and efficacy of darbepoetin alfa in previously untreated extensive-stage small-cell lung cancer treated with platinum plus etoposide. J Clin Oncol 26: 2342-2349

Pronzato P, Cortesi E, van der Rijt C, Moreno-Nogueira A, Raimundo D, Ostler P, Bols A, Rosso R (2002) Early intervention with epoetin alfa in breast cancer (BC) patients (pts) undergoing chemotherapy (CT): results of a randomized, multicenter, phase IIIb study (EPO-INT-47 Study Group). Ann Oncol 13: 168

Razzouk BI, Hord JD, Hockenberry M, Hinds PS, Feusner J, Williams D, Rackoff WR (2006) Double-blind, placebo-controlled study of quality of life, hematologic end points, and safety of weekly epoetin alfa in children with cancer receiving myelosuppressive chemotherapy. J Clin Oncol 24: $3583-3589$

Rose E, Rai K, Revicki D, Brown R, Reblando J (1994) Clinical and health status assessments in anemic chronic lymphocytic leukemia (CLL) patients treated with epoetin alfa (EPO). Blood 84: 526a (Abstract 2091)

Ross SD, Allen IE, Henry DH, Seaman C, Sercus B, Goodnough LT (2006) Clinical benefits and risks associated with epoetin and darbepoetin in patients with chemotherapy-induced anemia: a systematic review of the literature. Clin Ther 28: 801-831

Savonije JH, van Groeningen CJ, van Bochove A, Honkoop AH, van Felius CL, Wormhoudt LW, Giaccone G (2005) Effects of early intervention with epoetin alfa on transfusion requirement, hemoglobin level and survival during platinum-based chemotherapy: results of a multicenter randomised controlled trial. Eur J Cancer 41: 1560-1569

Schwartz RN (2007) Anemia in patients with cancer: incidence, causes, impact, management, and use of treatment guidelines and protocols. $\mathrm{Am}$ J Health Syst Pharm 64: S5-13

Seidenfeld J, Piper M, Bohlius J, Weingart O, Trelle S, Engert A, Skoetz N, Schwarzer G, Wilson J, Brunskill S, Hyde C, Bonnell C, Ziegler KM, Aronson N (2006) Comparative Effectiveness of Epoetin and Darbepoetin for Managing Anemia in Patients Undergoing Cancer Treatment Comparative Effectiveness Review No. 3. (Prepared by Blue Cross and Blue Shield Association Technology Evaluation Center Evidence-based Practice Center under Contract No. 290-02-0026). May 2006. Available from: http://effectivehealthcare.ahrq.gov/repFiles/EPO\%20Final.pdf. Agency for Healthcare Research and Quality: Rockville, MD, [Accessed February 27, 2008]

Sinclair AM, Rogers N, Busse L, Archibeque I, Brown W, Kassner PD, Watson JEV, Arnold GE, Nguyen KCQ, Powers S, Elliott S (2008) Erythropoietin receptor transcription is neither elevated nor predictive of surface expression in human tumour cells. Br J Cancer 98: 1059- 1067

Sinclair AM, Todd MD, Forsythe K, Knox SJ, Elliott S, Begley CG (2007) Expression and function of erythropoietin receptors in tumors: implications for the use of erythropoiesis-stimulating agents in cancer patients. Cancer 110: $477-488$

Singh AK, Szczech L, Tang KL, Barnhart H, Sapp S, Wolfson M, Reddan D (2006) Correction of anemia with epoetin alfa in chronic kidney disease. $N$ Engl J Med 355: 2085-2098

Smith Jr RE., Aapro MS, Ludwig H, Pinter T, Smakal M, Ciuleanu TE, Chen L, Lillie T, Glaspy JA (2008) Darbepoetin alfa for the treatment of anemia in patients with active cancer not receiving chemotherapy or radiotherapy: results of a phase III, multicenter, randomized, double-blind, placebo-controlled study. J Clin Oncol 26: 1040-1050

Smith Jr RE., Tchekmedyian NS, Chan D, Meza LA, Northfelt DW, Patel R, Austin M, Colowick AB, Rossi G, Glaspy J (2003) A dose- and schedulefinding study of darbepoetin alpha for the treatment of chronic anaemia of cancer. Br J Cancer 88: $1851-1858$

Spence RK (2007) Medical and economic impact of anemia in hospitalized patients. Am J Health Syst Pharm 64: S3-10

Strauss HG, Haensgen G, Dunst J, Hayward CR, Burger HU, Scherhag A, Koelbl H (2008) Effects of anemia correction with epoetin beta in patients receiving radiochemotherapy for advanced cervical cancer. Int $J$ Gynecol Cancer 18: 515-524

Takeshita A, Shinjo K, Higuchi M, Miyawaki S, Takemoto Y, Kishimoto Y, Saito K, Takuchi H, Kuriyama K, Kimura Y, Asou N, Takahashi M, Hotta T, Kanamaru A, Ueda R, Ohno R (2000) Quantitative expression of erythropoietin receptor (EPO-R) on acute leukaemia cells: relationships between the amount of EPO-R and $\mathrm{CD}$ phenotypes, in vitro proliferative response, the amount of other cytokine receptors and clinical prognosis. Japan Adult Leukaemia Study Group. Br J Haematol 108: $55-63$

Taylor K, Ganly P, Charu V, DiBenedetto J, Kracht K, Rossi G, Hernandez E (2005) Randomized, double-blind, placebo-controlled study of darbepoetin 
alfa every 3 weeks for the treatment of chemotherapy-induced anemia. Blood 106: Abstract 3556

ten Bokkel Huinink WW, de Swart CA, van Toorn DW, Morack G, Breed WP, Hillen HF, van der Hoeven JJ, Reed NS, Fairlamb DJ, Chan SY, Godfrey KA, Kristensen GB, van Tinteren H, Ehmer B (1998) Controlled multicentre study of the influence of subcutaneous recombinant human erythropoietin on anaemia and transfusion dependency in patients with ovarian carcinoma treated with platinum-based chemotherapy. Med Oncol 15: $174-182$

Thatcher N, De Campos ES, Bell DR, Steward WP, Varghese G, Morant R, Vansteenkiste JF, Rosso R, Ewers SB, Sundal E, Schatzmann E, Stocker H (1999) Epoetin alpha prevents anaemia and reduces transfusion requirements in patients undergoing primarily platinum-based chemotherapy for small cell lung cancer. Br J Cancer 80: 396-402

Thomas G, Ali S, Hoebers FJ, Darcy KM, Rodgers WH, Patel M, Abulafia O, Lucci III JA, Begg AC (2008) Phase III trial to evaluate the efficacy of maintaining hemoglobin levels above $12.0 \mathrm{~g} / \mathrm{dl}$ with erythropoietin vs above $10.0 \mathrm{~g} / \mathrm{dl}$ without erythropoietin in anemic patients receiving concurrent radiation and cisplatin for cervical cancer. Gynecol Oncol 108: $317-325$

Thompson JA, Gilliland DG, Prchal JT, Bennett JM, Larholt K, Nelson RA, Rose EH, Dugan MH (2000) Effect of recombinant human erythropoietin combined with granulocyte/macrophage colony-stimulating factor in the treatment of patients with myelodysplastic syndrome. GM/EPO MDS Study Group. Blood 95: 1175-1179

Throuvalas N, Antonadou D, Boufi M, Lavey R, Malamos N (2000) Erythropoietin decreases transfusion requirements during radiotherapy. J Clin Oncol 19: Abstract 1558

Tonelli M, Hemmelgarn B, Reiman T, Manns B, Reaume MN, Lloyd A, Wiebe N, Klarenbach S (2009) Benefits and harms of erythropoiesis- stimulating agents for anemia related to cancer: a meta-analysis. CMAJ 180: E62-E71

Vadhan-Raj S, Skibber JM, Crane C, Bueso-Ramos CE, Rodriguez-Bigas MA, Feig BW, Lin EH, Ajani JA, Collard M, Johnson MM, Hamilton SR, JanJan N (2004) Randomized, double-blind, placebo-controlled trial of epoetin alfa (Procrit) in patients with rectal and gastric cancer undergoing chemo-radiotherapy (CT/RT) followed by surgery: early termination of the trial due to increased incidence of thrombo-embolic events (TEE). Blood 104: Abstract 2915

Vansteenkiste J, Pirker R, Massuti B, Barata F, Font A, Fiegl M, Siena S, Gateley J, Tomita D, Colowick AB, Musil J (2002) Double-blind, placebo-controlled, randomized phase III trial of darbepoetin alfa in lung cancer patients receiving chemotherapy. J Natl Cancer Inst 94: $1211-1220$

Westenfelder C, Baranowski RL (2000) Erythropoietin stimulates proliferation of human renal carcinoma cells. Kidney Int 58: 647-657

Wilkinson PM, Antonopoulos M, Lahousen M, Lind M, Kosmidis P (2006) Epoetin alfa in platinum-treated ovarian cancer patients: results of a multinational, multicentre, randomised trial. $\mathrm{Br} J$ Cancer 94: 947-954

Witzig TE, Silberstein PT, Loprinzi CL, Sloan JA, Novotny PJ, Mailliard JA, Rowland KM, Alberts SR, Krook JE, Levitt R, Morton RF (2005) Phase III, randomized, double-blind study of epoetin alfa compared with placebo in anemic patients receiving chemotherapy. J Clin Oncol 23: 2606-2617

Wright JR, Ung YC, Julian JA, Pritchard KI, Whelan TJ, Smith C, Szechtman B, Roa W, Mulroy L, Rudinskas L, Gagnon B, Okawara GS, Levine MN (2007) Randomized, double-blind, placebo-controlled trial of erythropoietin in non-small-cell lung cancer with disease-related anemia. J Clin Oncol 25: 1027-1032 